\title{
مقصد التعارف وأثره في القانون الدولي الإسلامي
}

\section{فريدة حايد}

\author{
الملخص \\ يهدف البحث إلى بيان أثر التعارف بين الشعوب والأمم، بوصفه مقصداً يتصل بالقيم الناظمة لبناء العلاقات

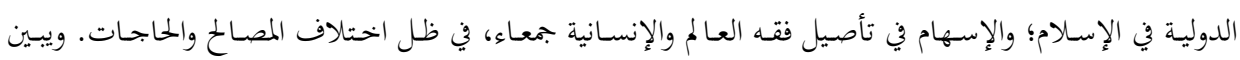 \\ البحث ضرورة بناء مقصد التعارُف على قيم الحضارة ومعاني الإسلام السامية، التي من بينها فقه التعارف، وما يقوم

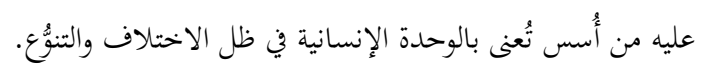 \\ الكلمات المفتاحية: التعارف، المقاصد، العلاقات الدولية، قيم الحضارة، الوحدة الإنسانية.
}

\section{The Purpose of Acquaintance among nations and its impact on Islamic International Law}

\section{Farida Hayed}

\begin{abstract}
Islam considers acquaintance among nations as an essential purpose related to values of constructing international relations. This study deals with the impact of this purpose on the Islamic international law, in order to contribute to the building of foundations for the jurisprudence of the world and humanity, taking into consideration the conflicting interests and needs. The study explains the need to build the purpose of acquaintance among nations on values of civilization prescribed by Islamic principles including the unity of humanity while respecting diversity and differences.
\end{abstract}

Keywords: acquaintance; purposes (maqasid); international relations; values of civilization; unity of humanity.

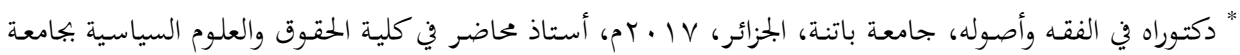

faridahaid@yahoo.fr : جيجل، الجزائر. البريد الإلكتروني

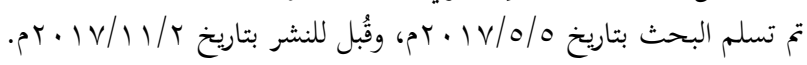


مقدمة:

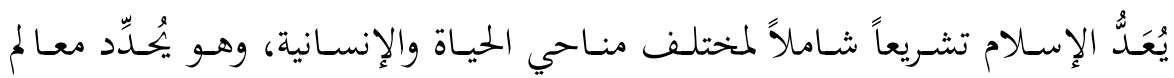

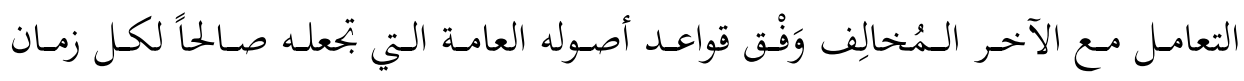

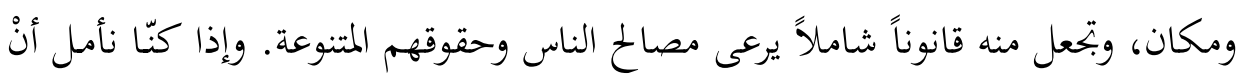

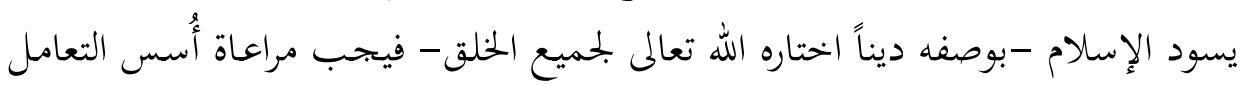

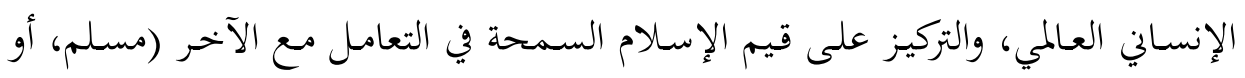
غير مسلم)؛ فالرحمة والتسامح والعدل -بوصفها مضامين الحق في الإسلام- هي السبيل

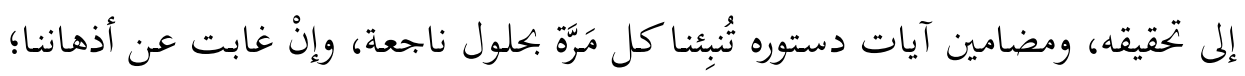

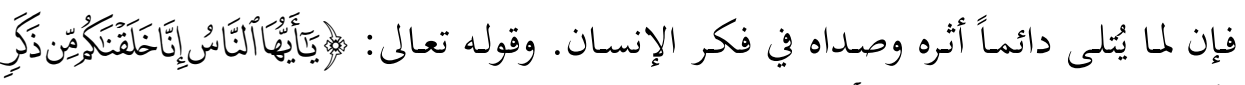

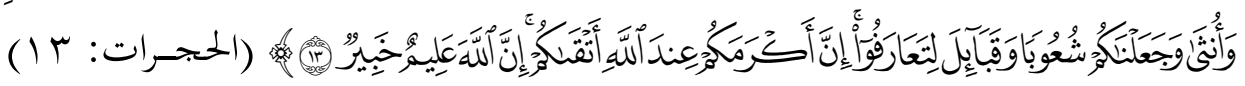
يُنبئ بأن الاختلاف في اللون والجنس واللسان والبلد هو وسيلة للتعارف والتعاون، وأن

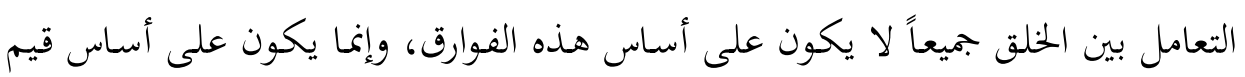

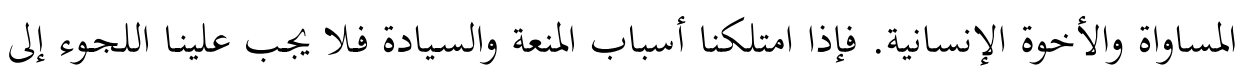

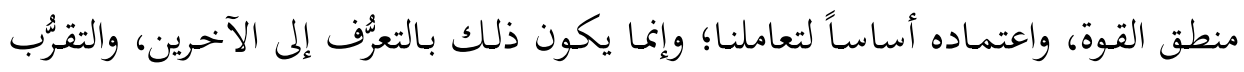

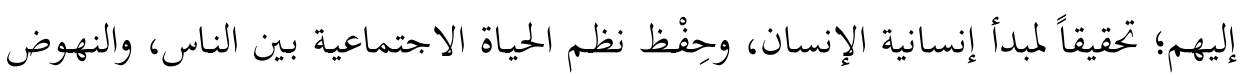
بالمحتمع. أمَّا إذا غلب علينا الضعف والتراخي فيجب إفساح البحال لمعرفة الآخر، وتعرُّف

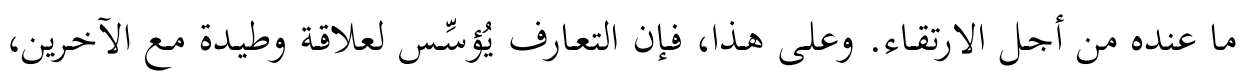

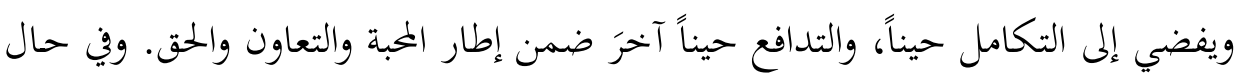

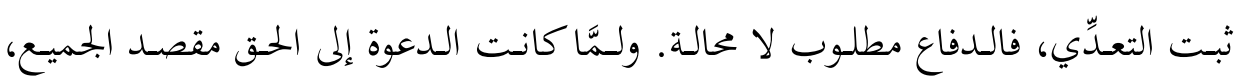

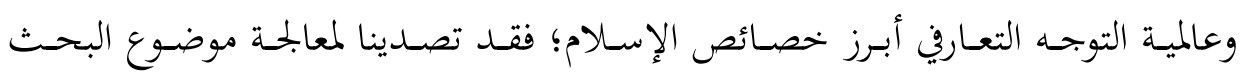
بمحاولة الإجابة عن التساؤل الآتي: ما أثر التعارف في العلاقات الدولية في الإسلام؟ التهاج وتتمثََّّل أهميــة البحــث في بيـان أثتر القـيم في العلاقـات الدوليـة والقـانون الـدولي

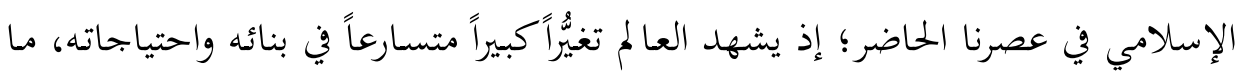


يتطلَّب سَنَّ قانون شامل للإنسانية جمعاء، وترسيخ قيم العدل والمساواة والتسامح بين بني

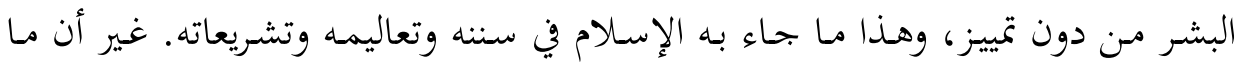

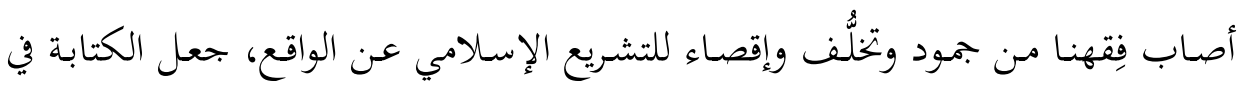
هذا النوع من الفقه متأخرة بالرغم مّّا نحوزه من تشريع عام، وقواعد شاملة. وبكثنا يروم

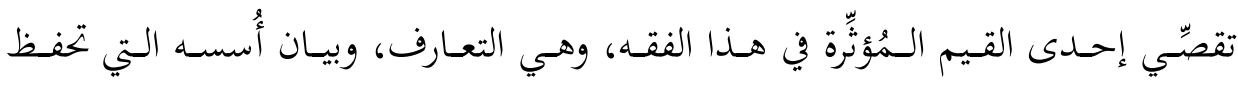
الإسلام، وتحفظ علاقاته بالآخرين؛ مسلمين، أو غير مسلمين.

واقتضـت طبيعـة الموضـوع استخدام المـنهج التحليلي لبيـان أثنر مقصـد التعـارف في

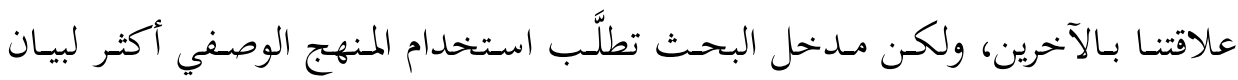
حقيقـة التعـارف، وحقيقـة القـانون الـدولي الإسـلامي والوضسعي ومعرفـة بعض التعريفـات

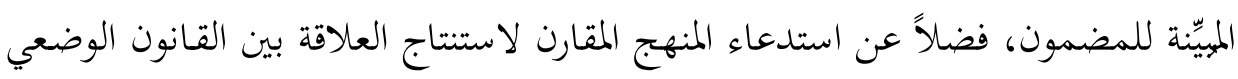
والقانون الشرعي القديم والمعاصر. وبعد اختيار الموضوع والانطلاق في البحث، وقفنا على بعض الدراسات المشابهة، من مثل: - بحث محمد أبو زهرة في كتابه القيّم: "العلاقات الدولية في الإسلام"؛ فهو أوَّل مَن

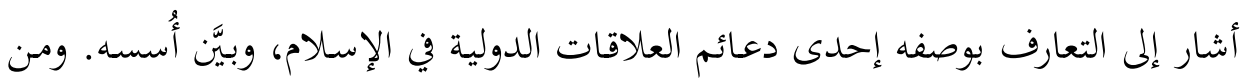

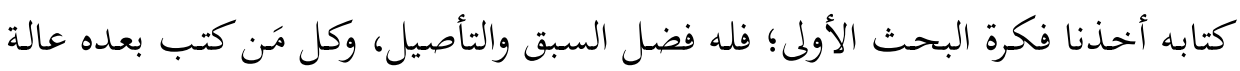
عليه.

- بحـث ناديـة محمـود مصطفى: "العلاقـات الدوليـة في الإسـلام: نهـو تأصـيل مـن

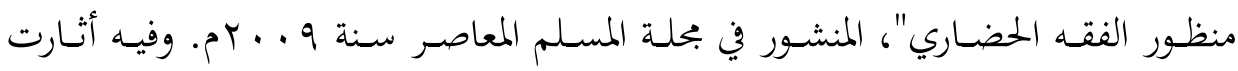
الكاتبة تساؤلات كثيرة عن كيفية التحوُّل من التأصيل الفقهي إلى التأصيل الحضاري

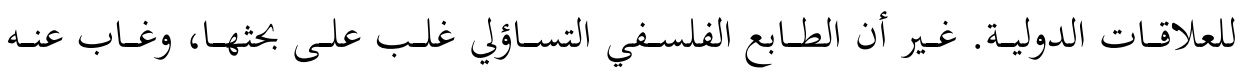

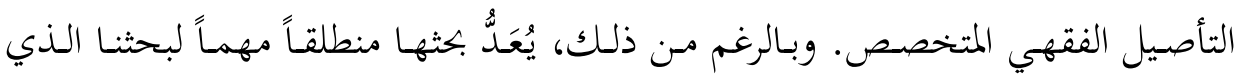
ركَّنا فيه على التعارف فقط، وبلغة فقهية أكثر وضوحاً وتفصيلاً. 


\section{أولاً: القيم المقاصدية العليا وأثرها في الفقه الحضاري}

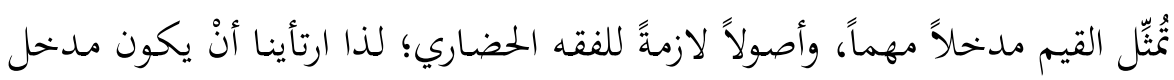

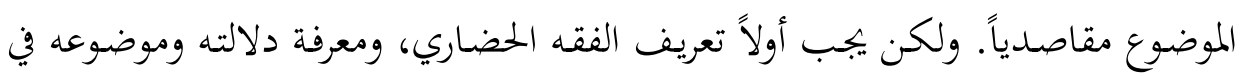

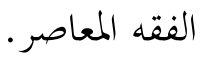

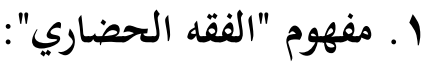

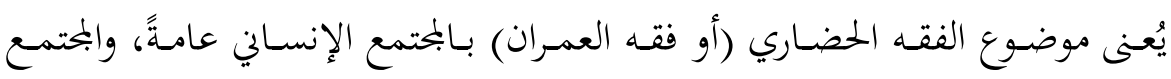

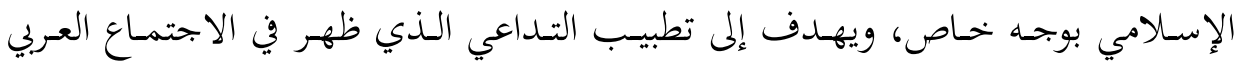

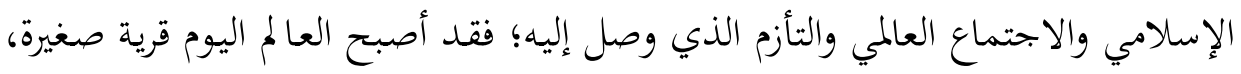

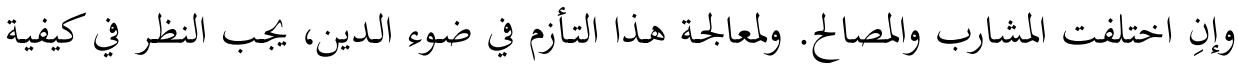

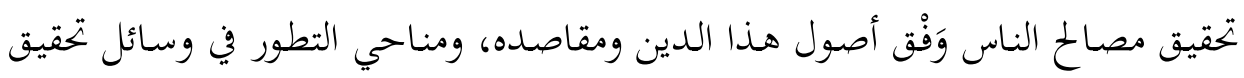

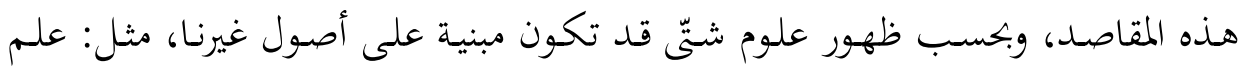

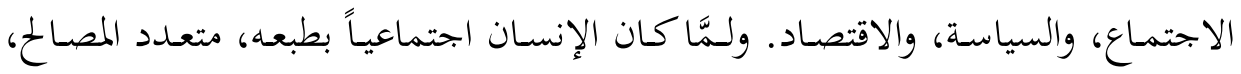

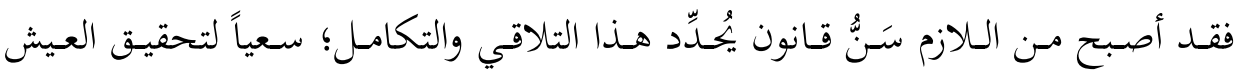

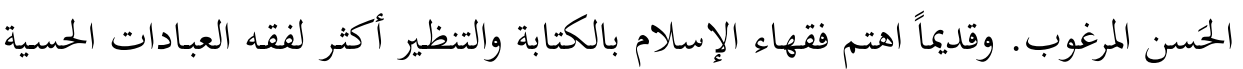

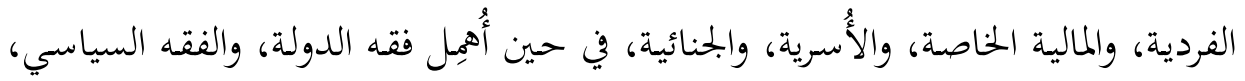

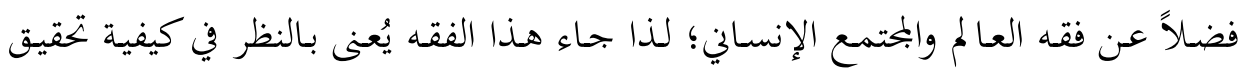

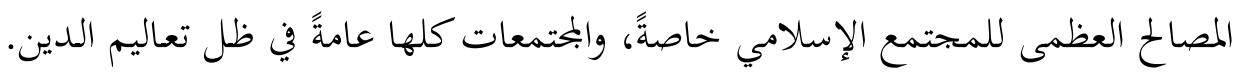

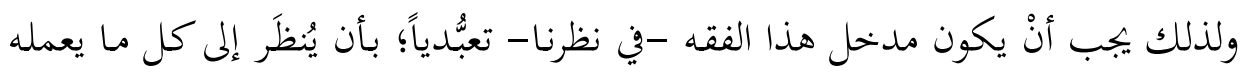

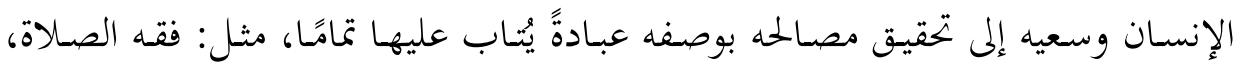

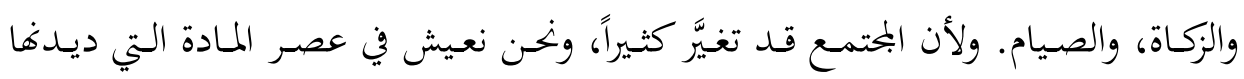

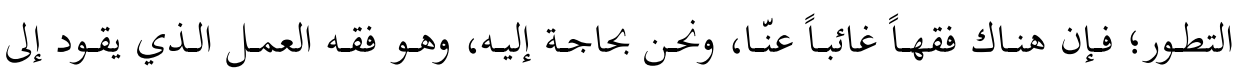

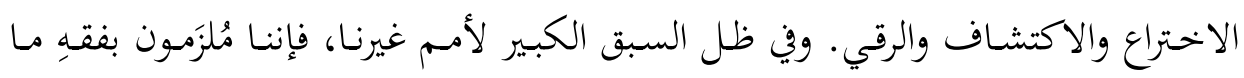

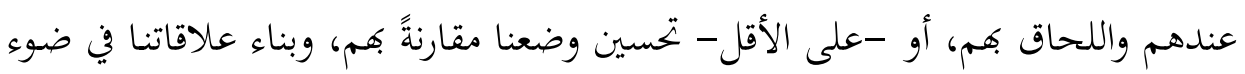

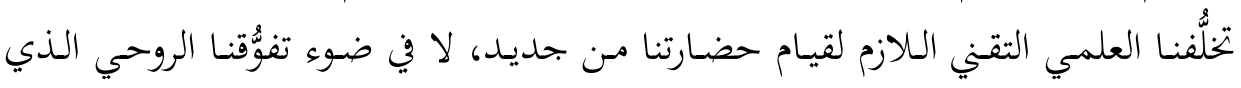




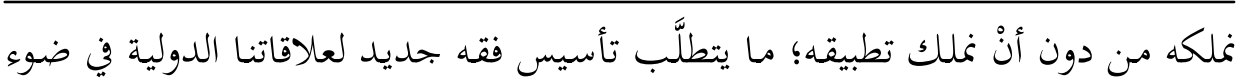
حضارة الغرب المعاصرة؛ فهو أوسع أبواب الفقه وأجلُّها، ولكلِّ وقتِ فِقُْهُهُ.

وهذا ما يُطلَق عليه اليوم اسم الفقه الحضاري الذي يراد به بيان أن دعوة الإسلام لم

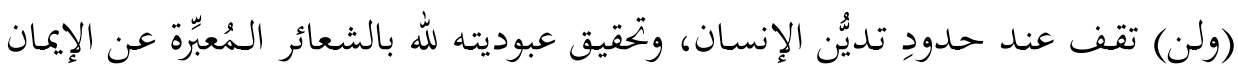

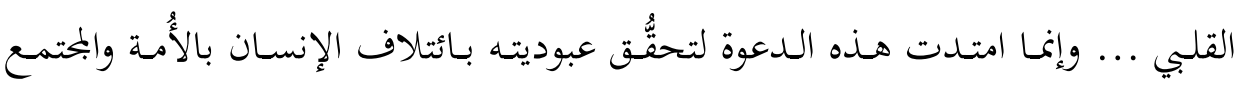

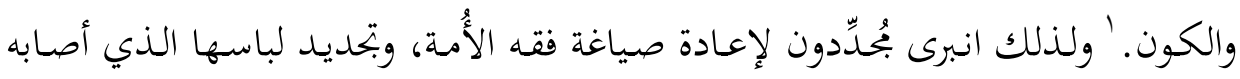

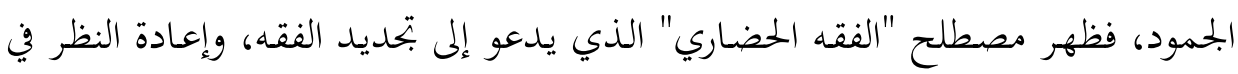

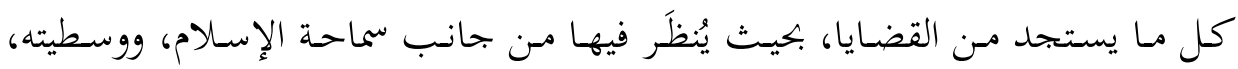

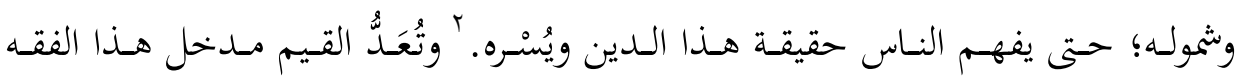

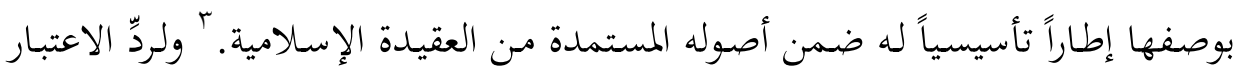

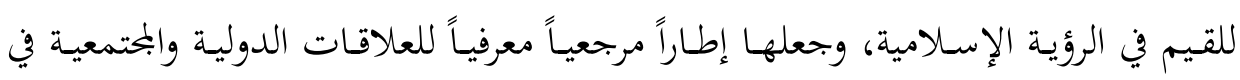
الإسلام، يجب ربط الفقه بوظيفته الحضارية، وهي العمران.

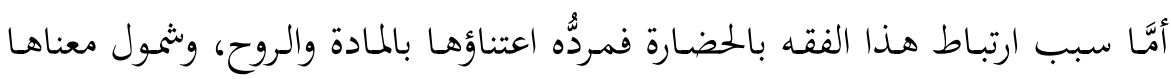

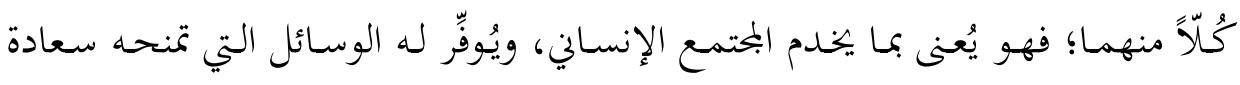

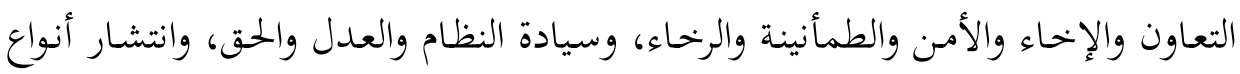

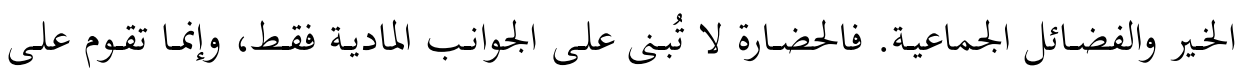

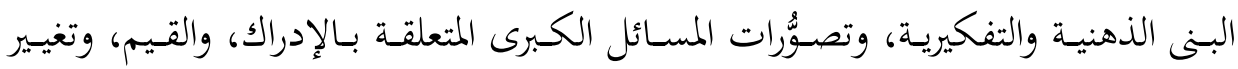

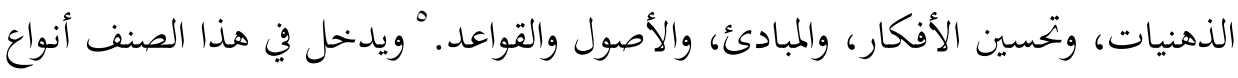

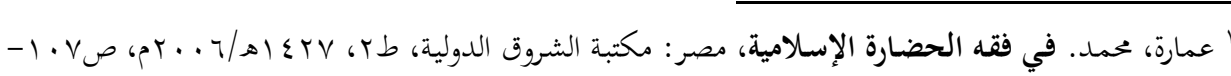
$.1 \cdot 1$

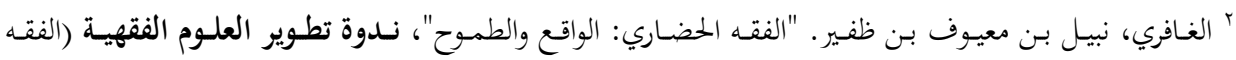

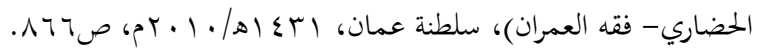

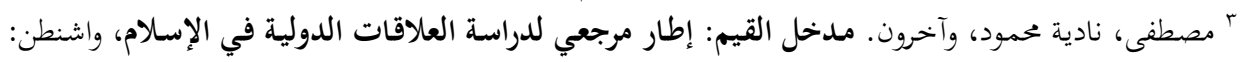

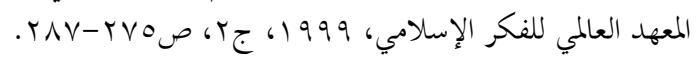
؛ المرجع السابق، صي خ وما بعدها.

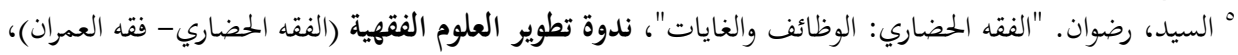

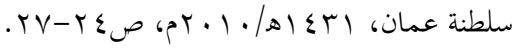




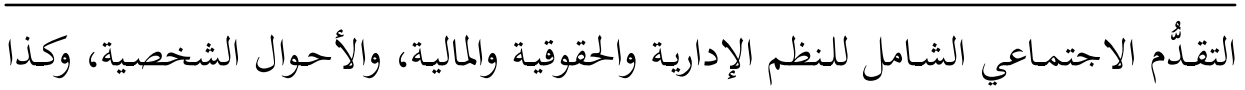
الأخهالق والتقاليـد والعادات الفاضـلات، وسـائر طرائق معاملة النـاس بعضهمم بعضـاً في علاقاقم المختلفة، وكل أنواع الثقافات والعلوم التي تخدم هذا الصنف.

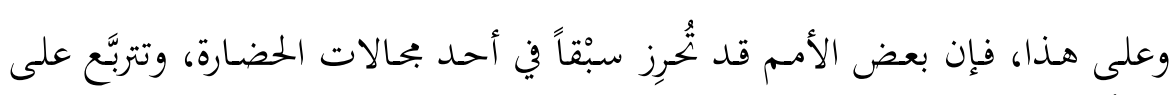
قمَّة التخلُّف في بحال آخر. غير أن الإسلام الذي يقوم على مبدأ تحقيق السعادة الأبدية

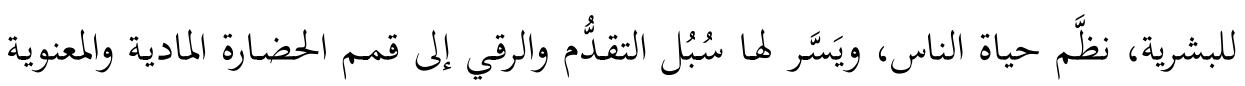
(الفردية، والاجتماعيـة). ولذلك عرَّف المعاصرون الفقـه الحضاري بأنه: "جهـد مـن أجل عودة الأمة إلى منابعها الأصلية، وإعطاء الأولوية للقيم والمعاني الإسالامية الفاضلة؛ لكي تُوجِّه الحياة وترشدها." " وقد شرح وزير الشؤون الإسالامية والأوقاف بماليزيا المقصود بهذا

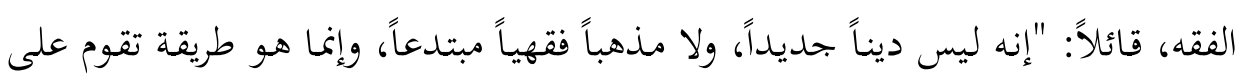

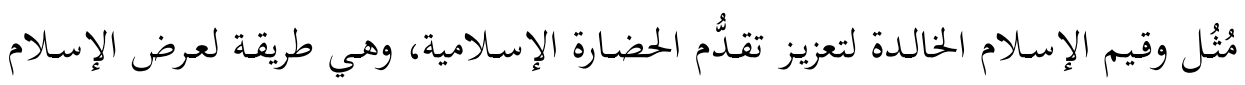
بواقعيـة وعمليـة، وعـودة الأمـة إلى مصـادرها الإسـلامية الأصسيلة ومبادئهـا القويمـة، ويعطي مشروع الإسـلام الحضاري مزيداً مسن الاهتمام لزيادة جحودة الحياة الإنسانية لكل النساس،

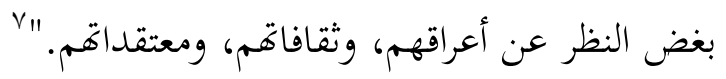

فالفقـه الحضـاري -إذن- هو مـا يُعنى بقيم الإسالام كلها، ومعانيه الشاملة التي تُؤثِّ في سلوك الإنسان وتفكيره قبـل الانصياع للعبادات البدنيـة مـن دون غيرهـا، وقد يتحوَّل

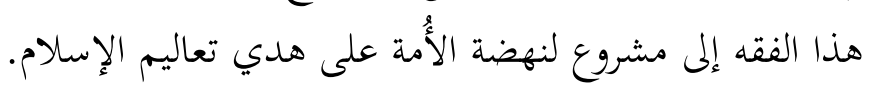

وقيم الإسـالام كثـيرة، ومتعـددة هي أُسسـه التي قـام عليهـا؛ منهـا مـا يتعلـق بكقـوق الإنسان مثل قيمة الحرية والكرامـة، ومنهـا مـا يتعلق بكقوق البحتمع مثل العمل والتعاون، ومنها ما يتعلق بحقوق الإنسانية مثل التعارف والتعاهد، ونشر السنّلم ... وهذا الجزء هو

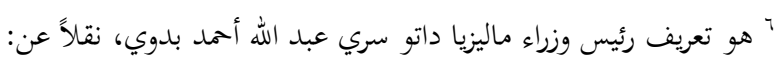
- بشير، محمد الشريف. "الإسلام الحضاري: مشروع ماليزي للنهوض باءئ بالأمة"، موقع السكينة الإلكتروني: - www.assakina.com

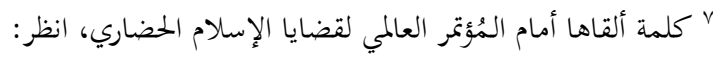

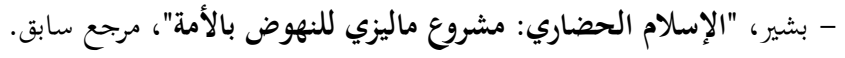


حسديث السـاعة، وإنْ كان لـدينا أصسول خاصـة بـه، إلا أننـا لم هـتم بـه، ولم نكتـب فيسه

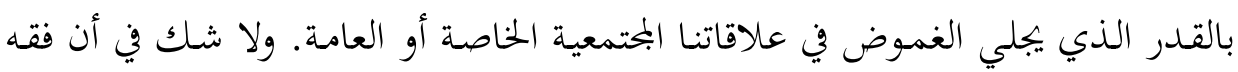

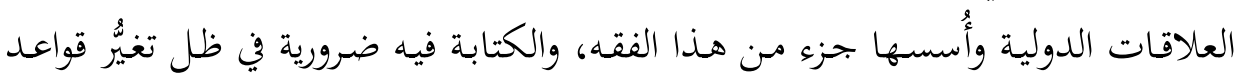

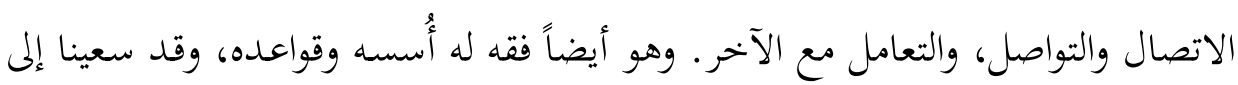

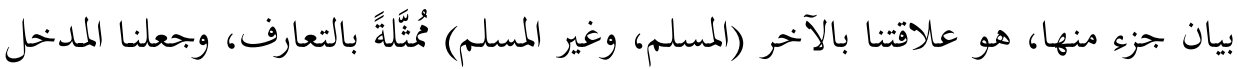

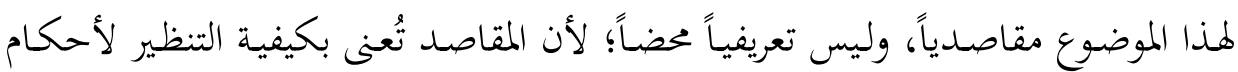

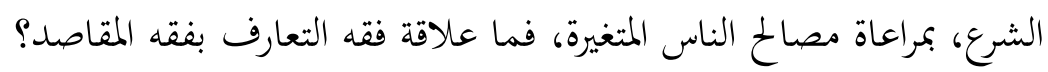

\section{Y. حقيقة المقاصد ودورها الحضاري:}

أطلق ابـن عاشـور على هــه المقاصـد اسـم المقاصـد العاليـة؛ للتنبيـه على أهَا تُمتِّل

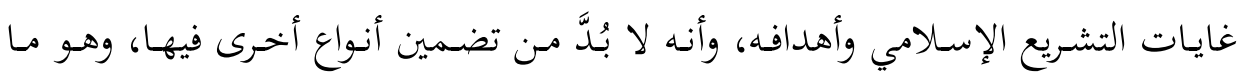

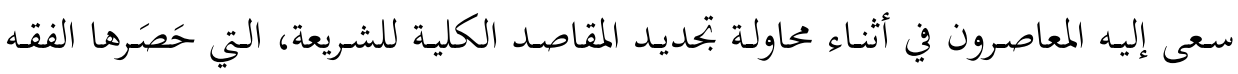

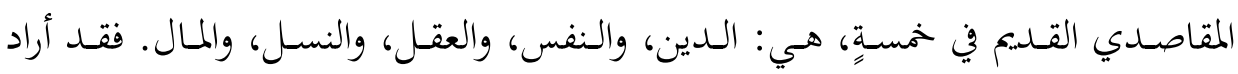

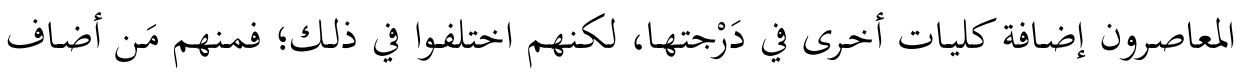

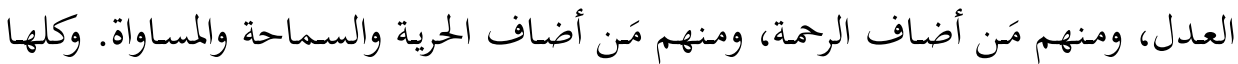

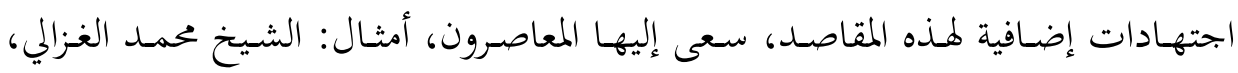
والشيخ القرضاوي، ومحمد رشيد رضا، ووهبة الزحيلي.

أمَّا الشـيخ ابـن عاشـور فقـــ جعلهـا في درجــة أرقى مـن درجــة الكليـات القطعيـة

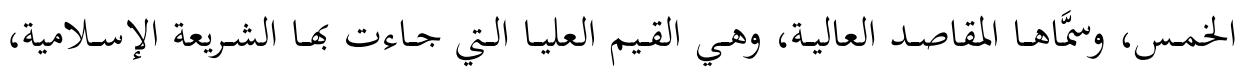

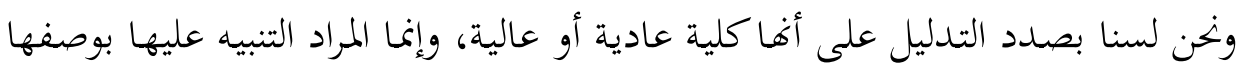

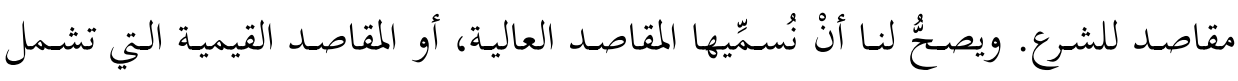

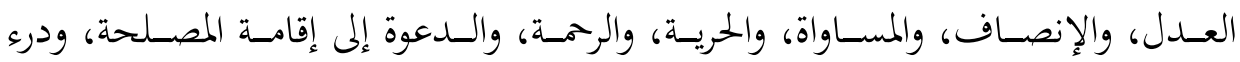

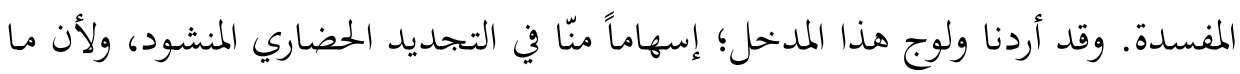

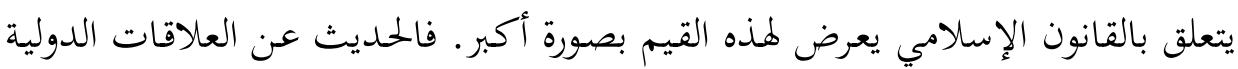

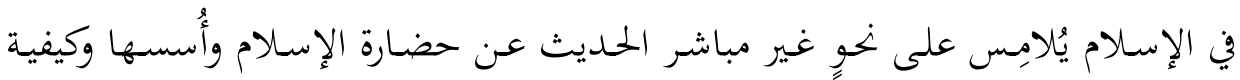




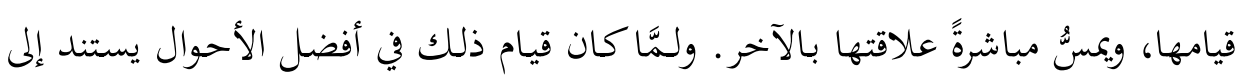

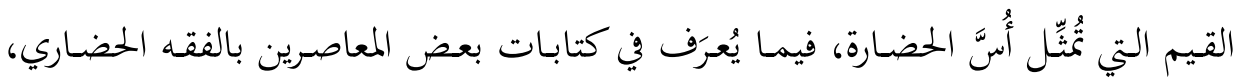

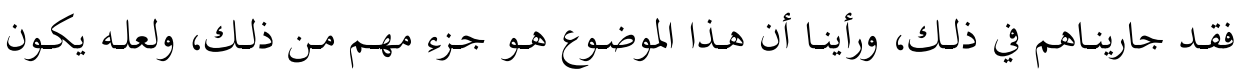

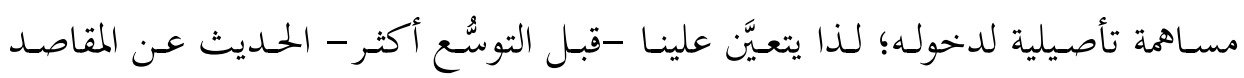
بصفة عامة، وعن أهم مقاصدها في نظر ابن عاشور.

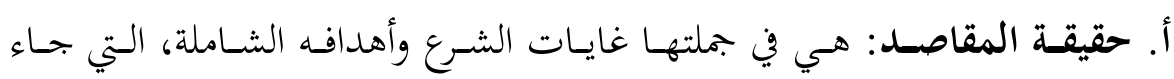

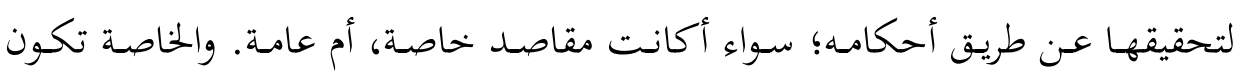

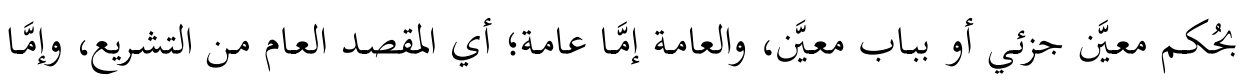

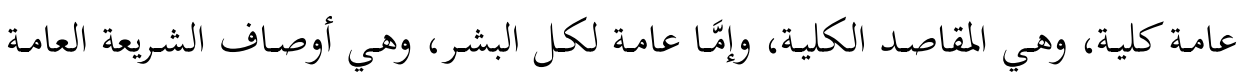

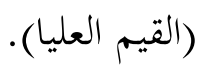

وتنقسـم المقاصـد تبعـاً لأهميتها، ودرجـة الحاجـة إليها، والتوقُّف عليهـا، إلى ثلاثة أقسام، هي: الضرورية (الكلية، العامة)، والحاجية، والتحسينية.

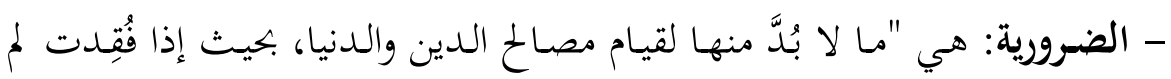

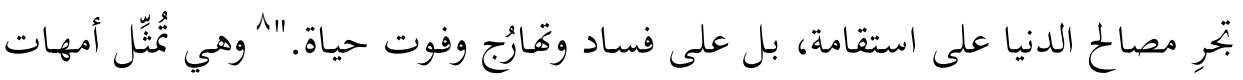

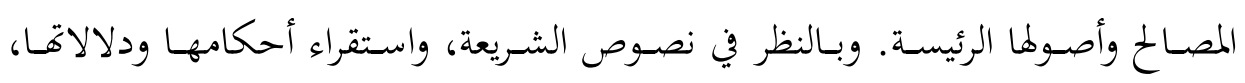

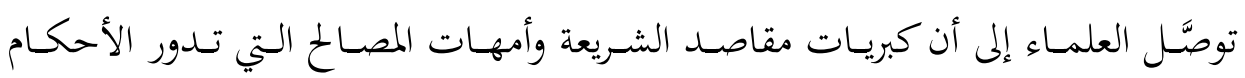

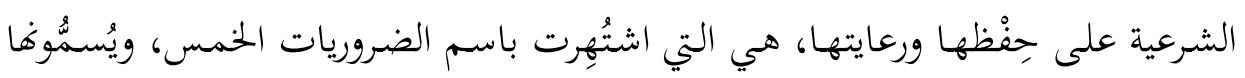

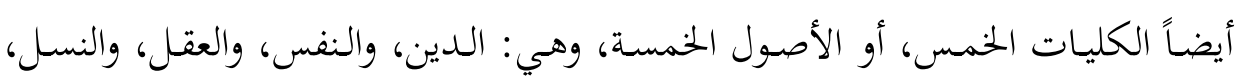

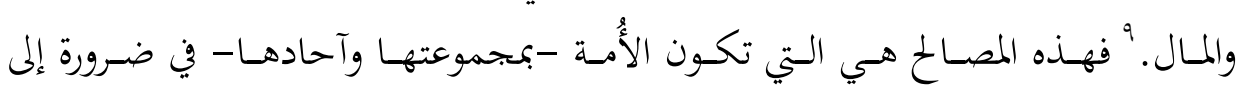

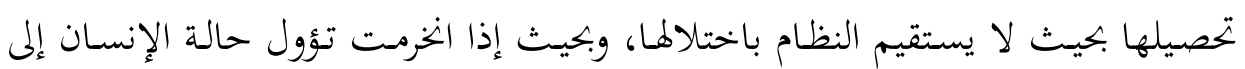
فساد وتمارج.

^ الشاطبي، أبو إسحاق. الموافقات في أصول الشريعة الإسلامية، تحقيق: عمد عبد الله دراز، بيروت: دار المعرفة،

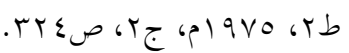

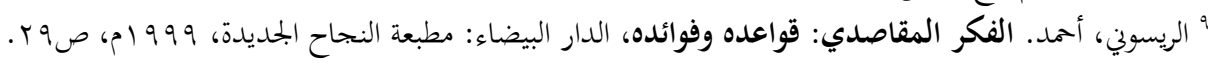




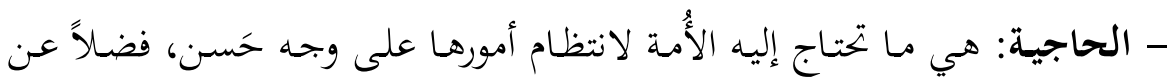

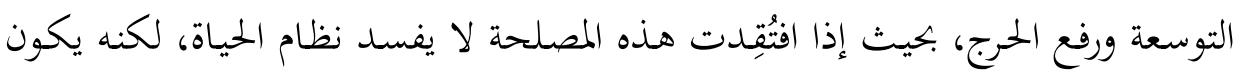

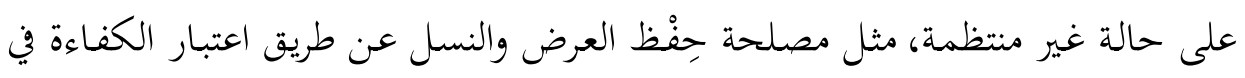
النكاح والشهود.

- التحسينية: هي التي يكصل بها كمال حال الأُمة في نظامها. وهذه المصلحة تُمثّل

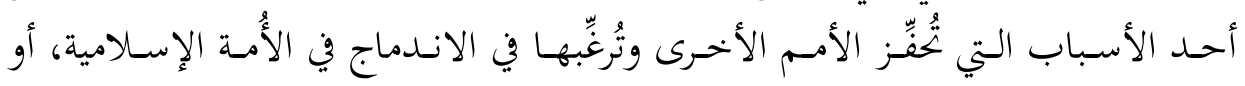

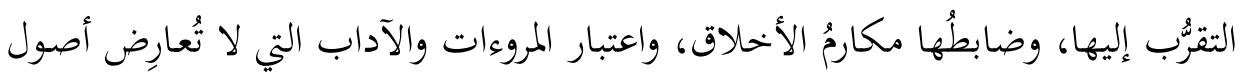

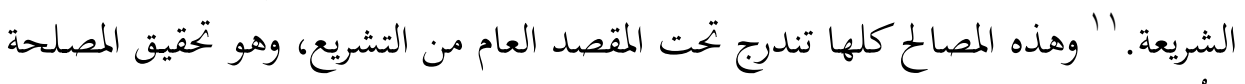

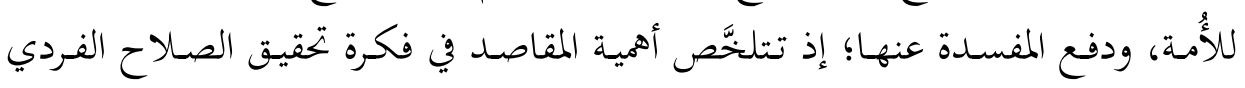

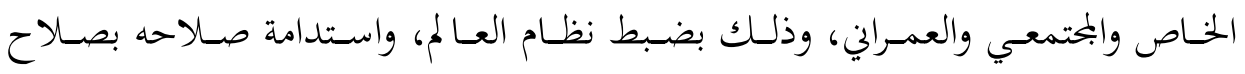

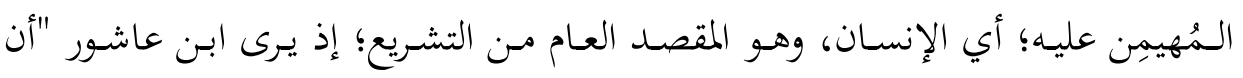

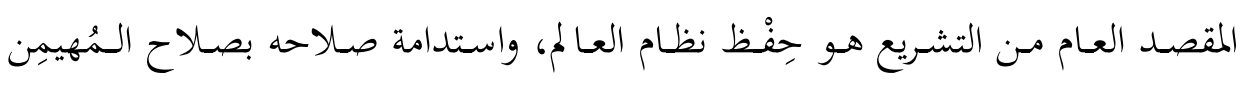

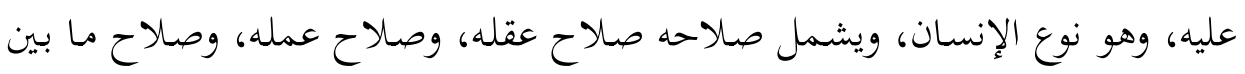

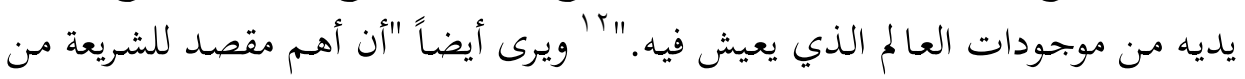

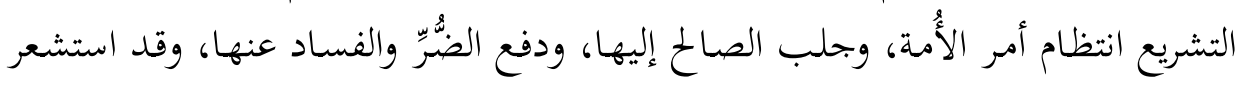

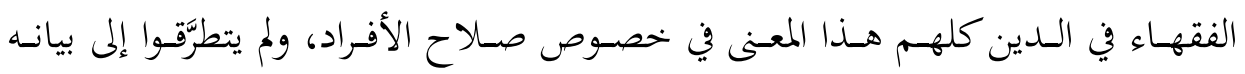

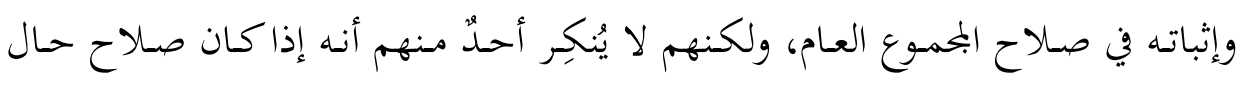

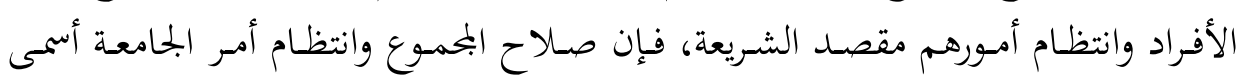

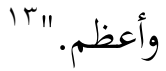

وهو يشير هنا إلى أن أهم مقصد للشريعة هو مقصد إصلاح العالم كله، والأُمة

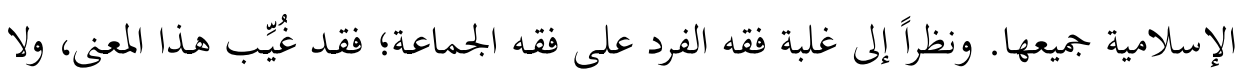

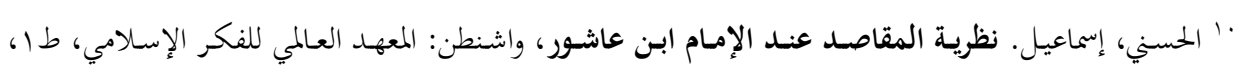

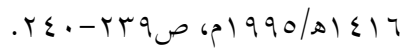

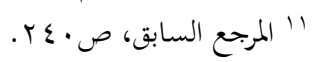
"1 ابن عاشور، حمد الطاهر م مقاصد الشريعة الإسلامية، تحقيق: عمد الحبيب بن الخوجة، قطر : وزارة الأوقاف

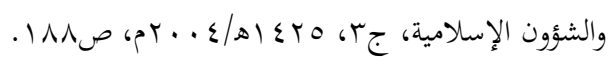

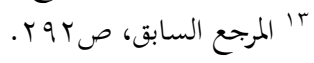




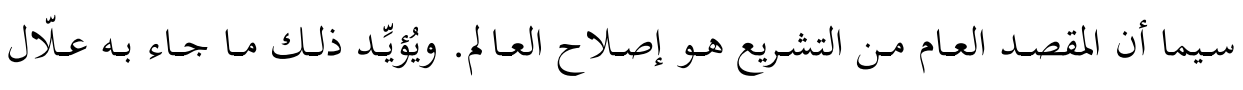

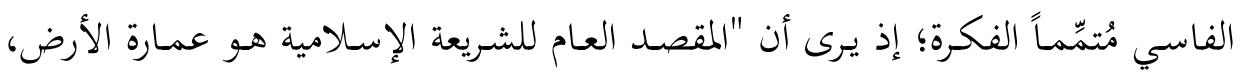

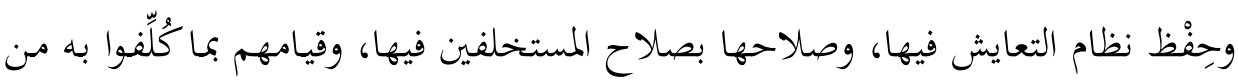

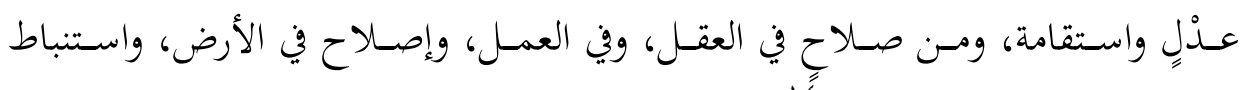

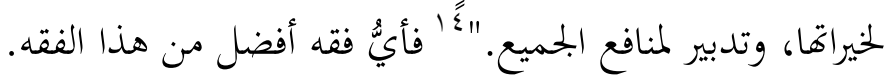

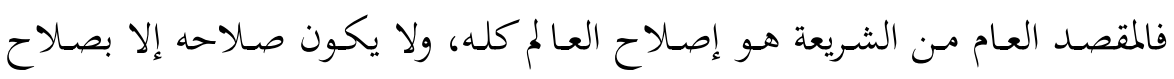

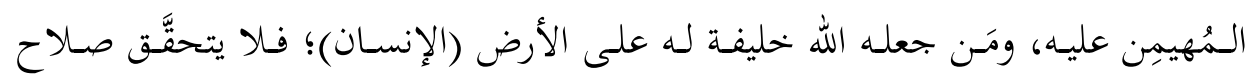

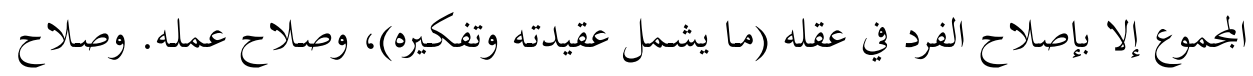

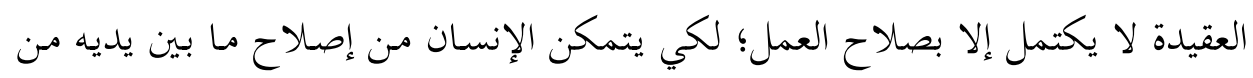

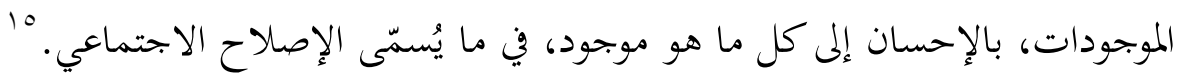

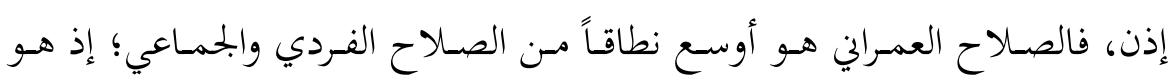

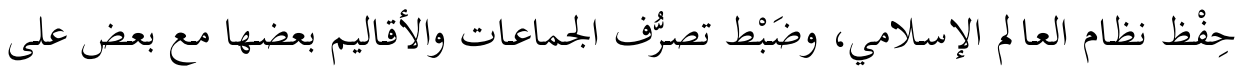

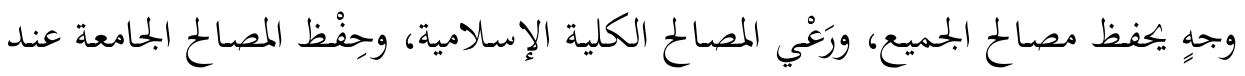

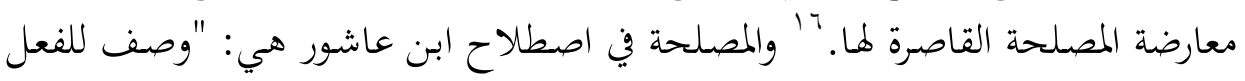

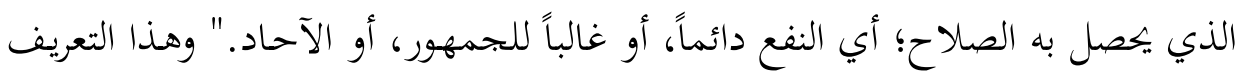

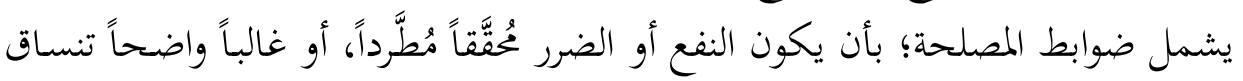

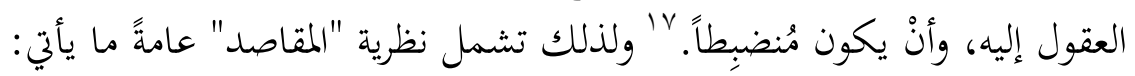

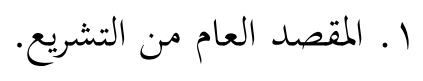

r. r. أوصاف الشريعة (مقاصدها العالية).

r. المقاصد العامة للشريعة (الكليات، أو الضروريات).

عـ المقاصد الجزئية والخاصة.

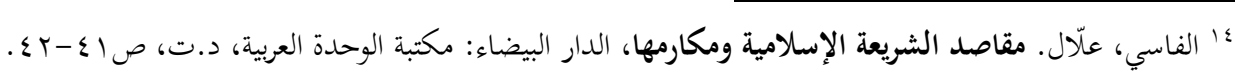

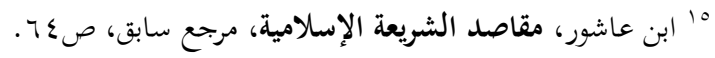

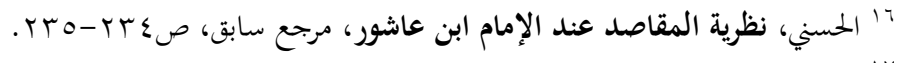

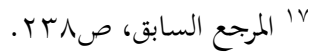


وقد سبق الحديث عن المقصد العام من التشريع، وهو -في حقيقته- قَصْد الشريعة

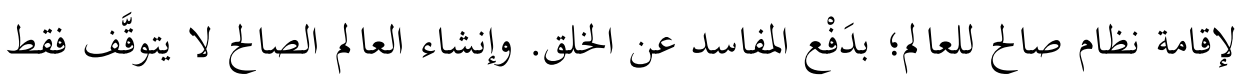

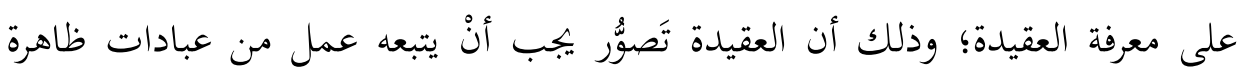

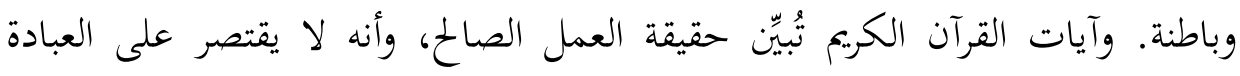
فحسب، بل هو السعي في الأرض، وإعمارها، والسير في مناكبها، وبناء كل صالح فيها؛

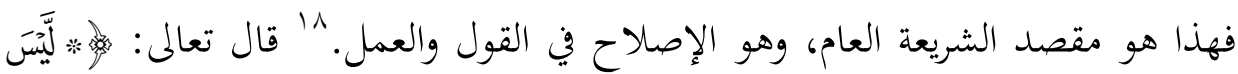

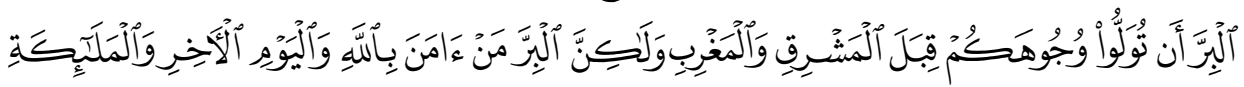

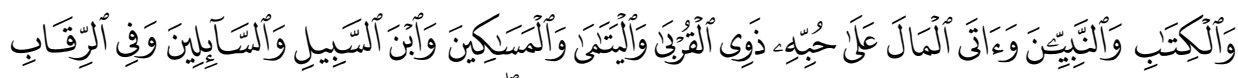

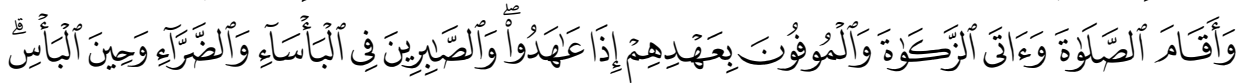

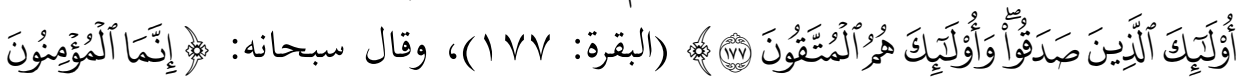

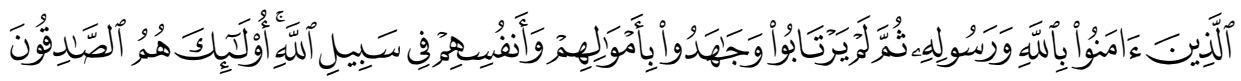

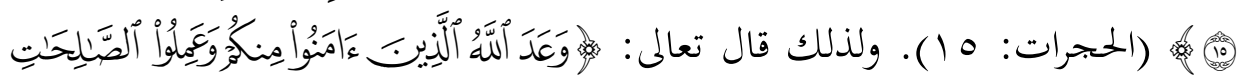

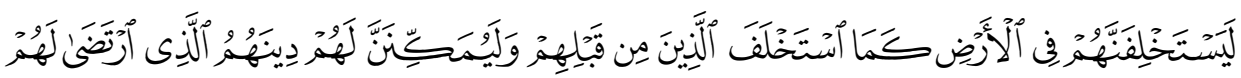

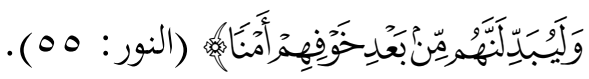

أمَّا أوصـاف الشـريعة فهي مقاصـدها العاليـة التي لا تنفـك عن الشـريعة الإسـلامية

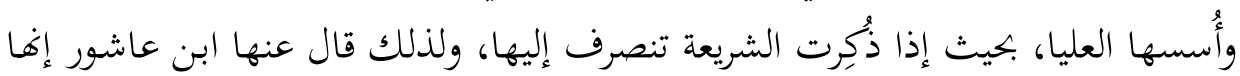

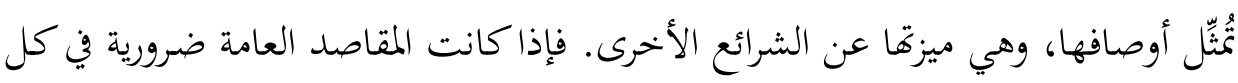

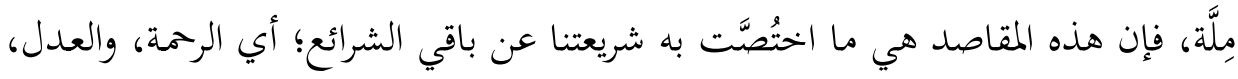

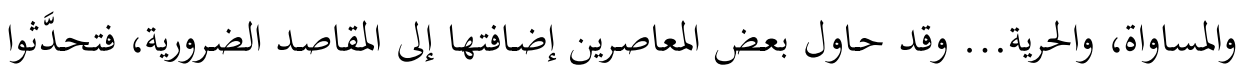

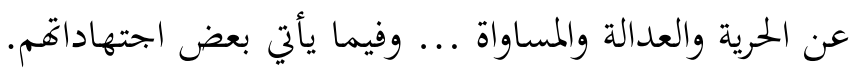
أضاف القرضاوي الأمن بوصفه مقصداً ضرورياً، ومنه الكفاية (أي الأمن الغذائي)،

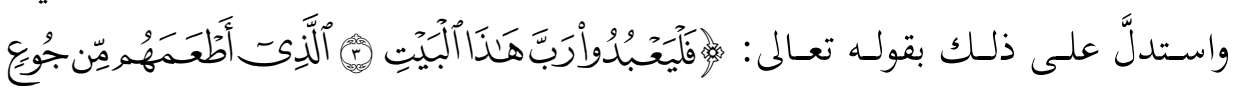

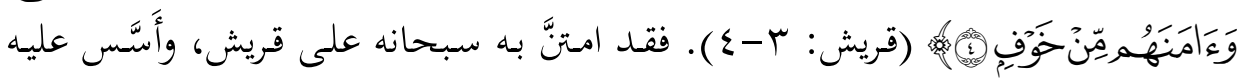

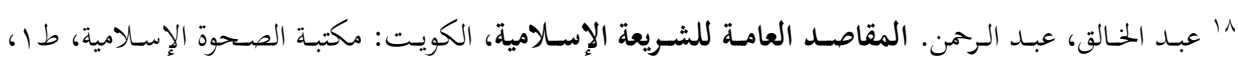




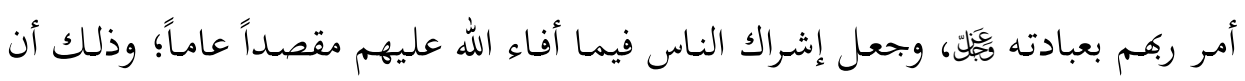

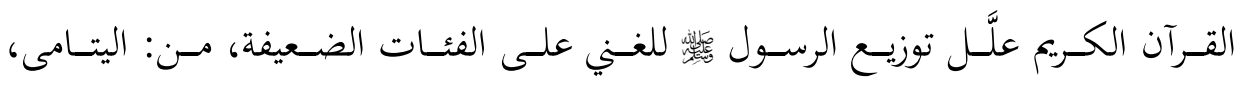

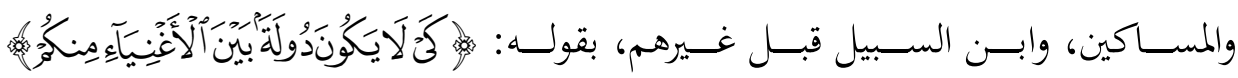
${ }^{19} \cdot(V:$ (الحشر)

وأضـاف أيضـاً العـل، والقسط، والإخـاء، والتكافل، والحريـة، والكرامة، وجعلها

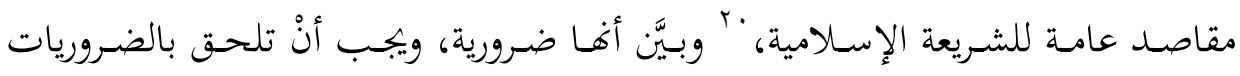

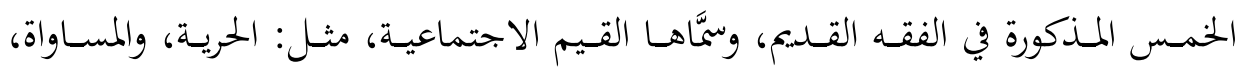

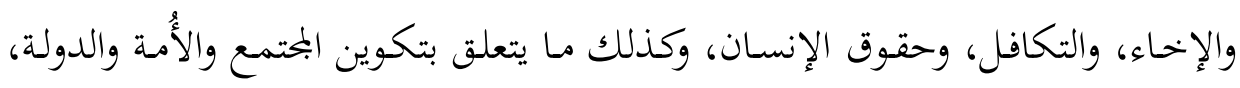

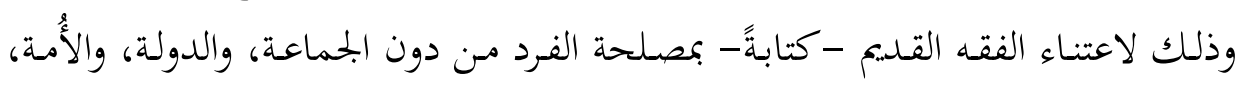

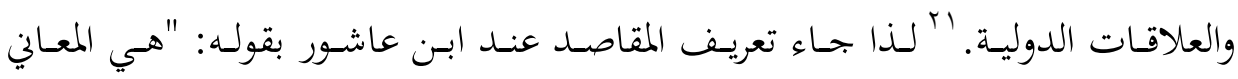

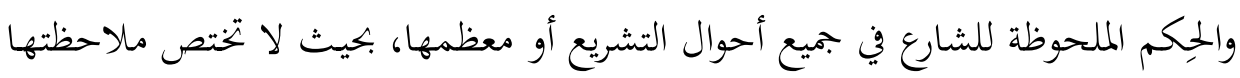

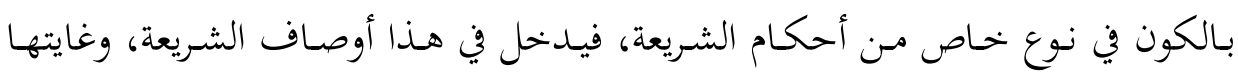

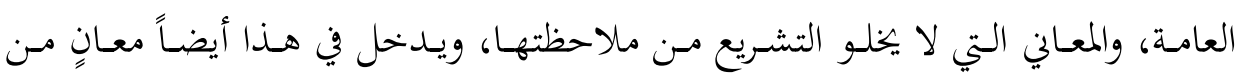

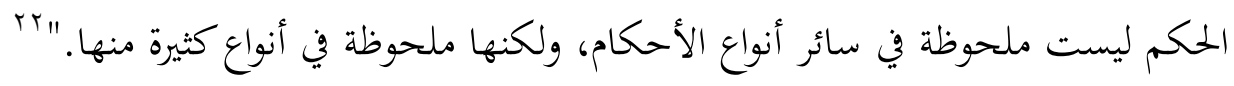

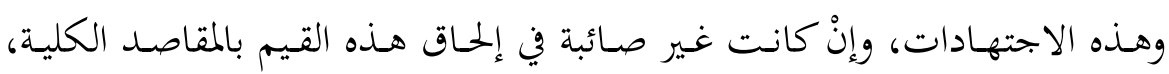

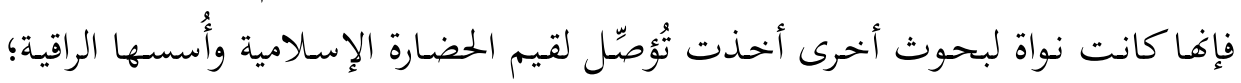

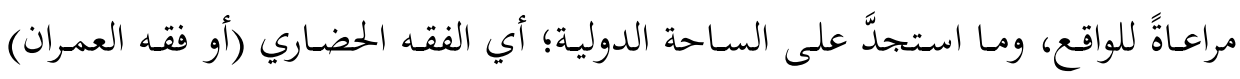

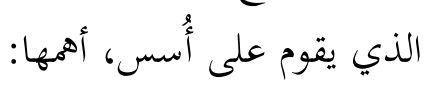

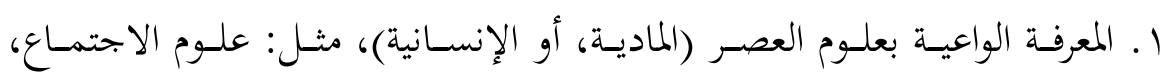
والطب، والهندسة، وعلوم الأديان.

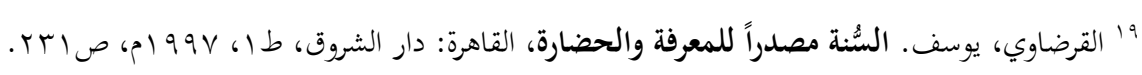

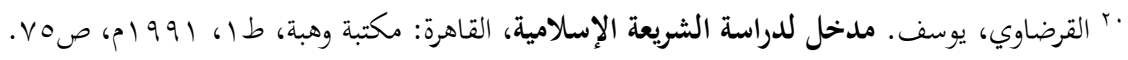

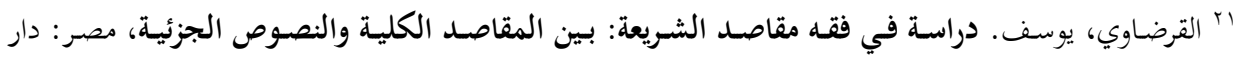

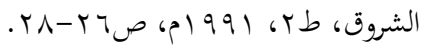

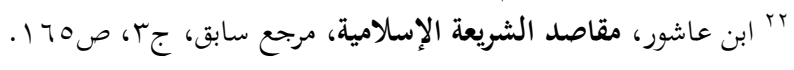




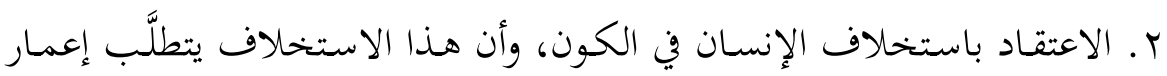

$$
\text { الأرض وبناءها لا الإفساد فيها وتخريبها. }
$$

r. التعارف والتحاور مع الآخر الذي يقود إلى التلاقح، والتفاعل، والتعاون، وتحقيق

$$
\text { الأصلح. }
$$

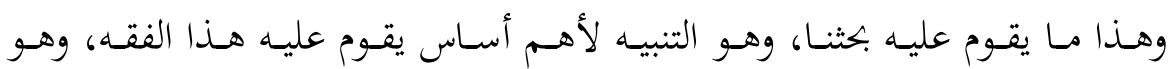

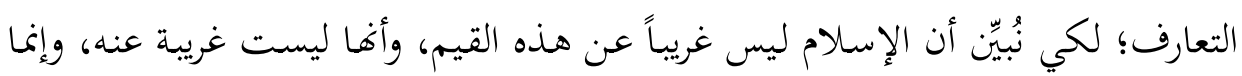

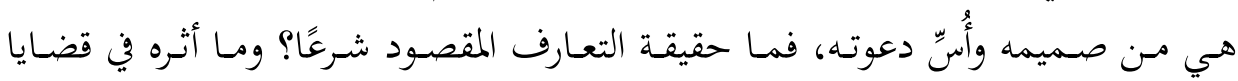

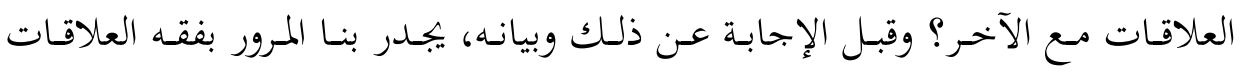

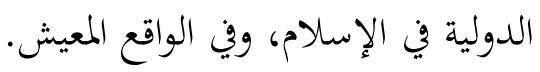

\section{ثانياً: العلاقات الدولية بين الواقع والقانون}

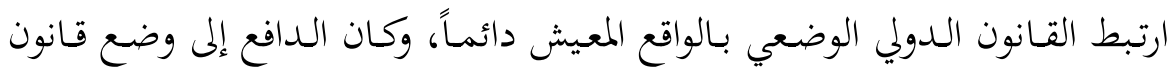

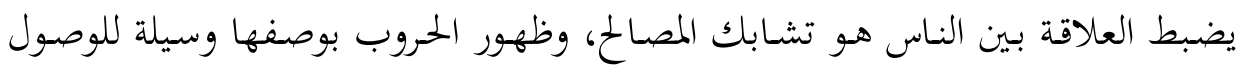
إليها. وهذا القانون بحاجة إلى تطوير وتغيير كما سيبدو لاحقاً.

\section{Iـ القانون الدولي في الدراسات القانونية:}

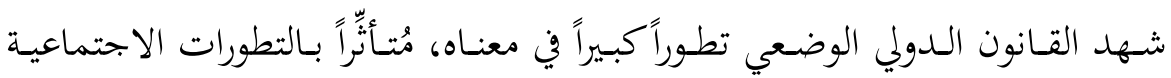

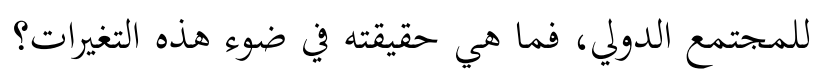

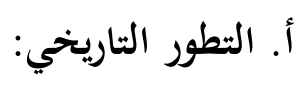

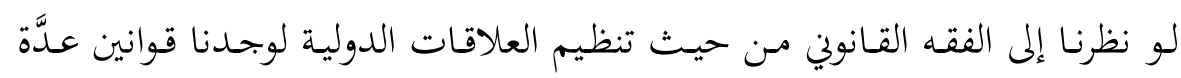

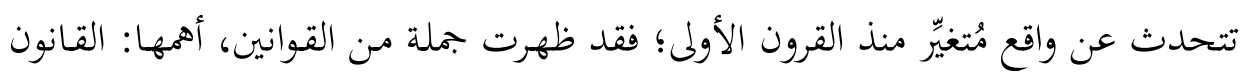

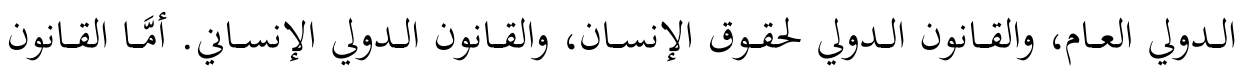

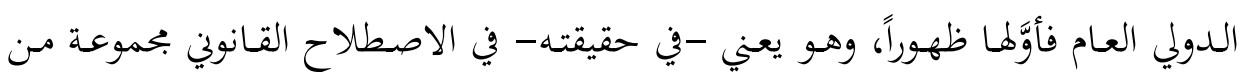

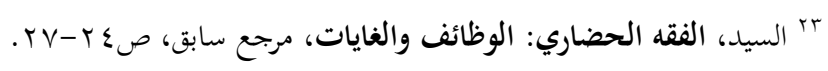


القواعد وُضِعت للحدِّ مـن الحهروب الدينيـة وغيرهـا، حيـث كانت العلاقات الدولية بحـرد سلسـلة مـن الحــروب المتتاليـة. وقـد ظهر هـذا القـانون في كنـف الـدول الأوروبيـة بتوقيـع معاهـات بـين هـذه الدول خاصـةً، وكانـت هـذه المعاهـدات هـي الترجمة القانونيـة الأولى ألى

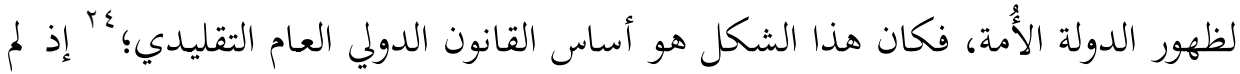

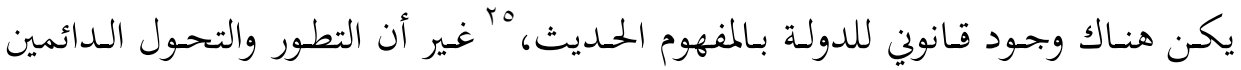
للمجتمع الدولي أدَّيا أيضاً إلى تطور القانون الدولي العام. والجحدير بالذكر أن هذا القانون كان أوروبياً عاماً فقط، ومهمته تنظيم التعايش بين القوى المتنافسة على قاعدة التوازن. وقانون التوازن يعني توزيع القوة في أوروبـا بين الدول الكبرى على نحوٍ متسـاوٍٍ مـا رسَّخ الاستعمار، وشتجَّعه، ولم يمنـع اللجـوء الشـرعي إلى القوة، ثم تطور أكثر في القرن التاسع عشر نتيجة تطور البحتمع، وظهور دول أخرى، فضالًا عن ظهور بحموعة منظمات دولية، ومعاهـدات متعـددة الأطـراف. وفي هـذه الآونـة ظهرت معاهـدات لاهـاي التي أباحـت الحرب بشروط، وهكذا أصبح القانون أكثر عالمية، وانحسر دور أوروبا وسيطرةقا على هذا

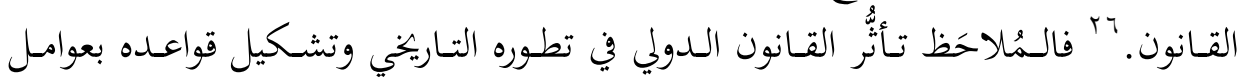
اجتماعية، وحروب وأحداث تاريخية.

وأمَّا شكل القـانون المعاصر فكان بعـد الحهرب العالميـة الثانيـة، ومـا خلَّفتـه مـن دمـار شامل، بعد سيادةٍ وإشاعةٍ لنظام القوة المفرطة، ثم تلا ذلك ظهور ملامح جديدة للعالم المعاصر، إذ برزت قوى جديدة، وانقسـم العالم بـين قوتين فقط، هما: الولايـات المتحدة

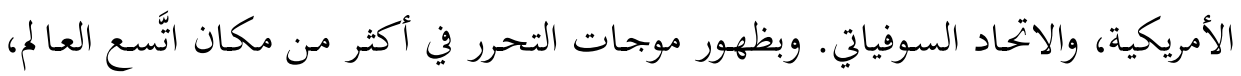
مُمُهِداً لظهور بحتمع دولي جديد يضـم دولاً ذات بنى سياسية، ومستويات تطور وتقاليد وتثقافة دينية مختلفة...6 فظهر تحالف جديد يدعو إلى ضرورة التطوير الديمقراطي للقانون الدولي والتعـاون الـدولي المتعـدد الأطـراف في إطـار المنظمـات الدوليـة، وهـو مـا أدَّى إلى

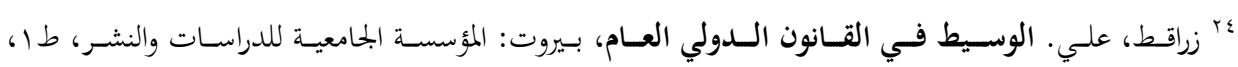

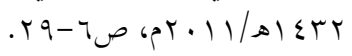

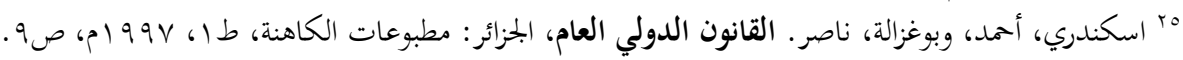

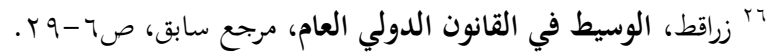

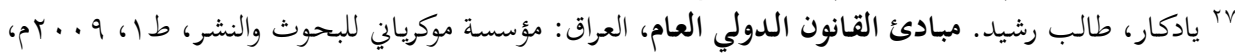




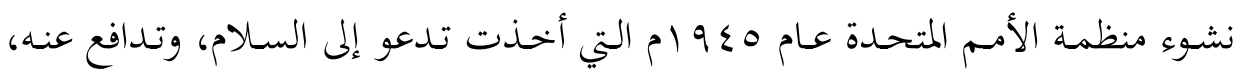

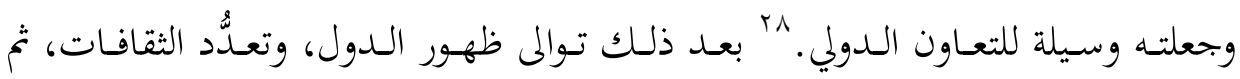

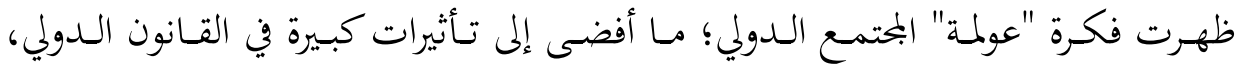

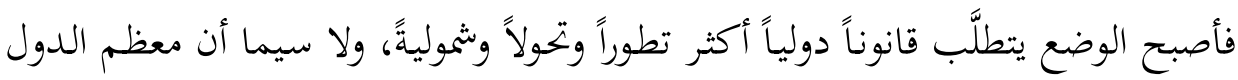
لم تشارك في وضعه؛ فلا يمنع شيء من تطويره وتغييره لمصلحة المجتمع الجحيد. وتأسيساً على ذلك، يمكن القول بأن هذا القانون هو "القانون المُطبَّق على المجتمع

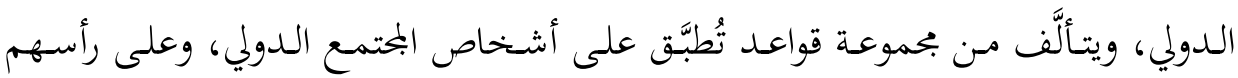

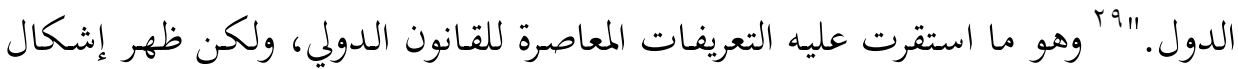

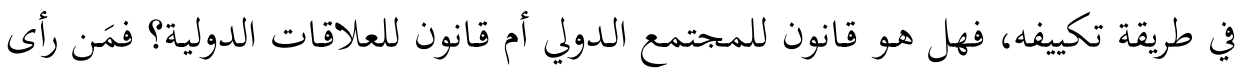

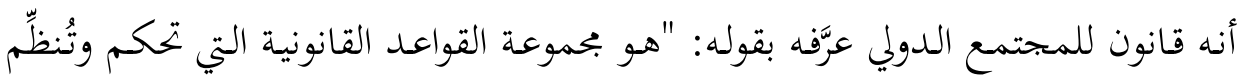

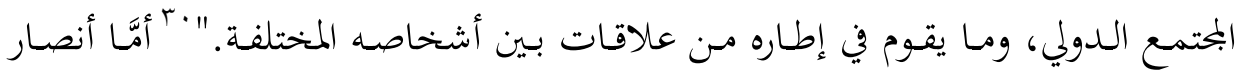

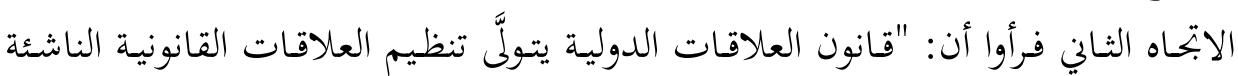

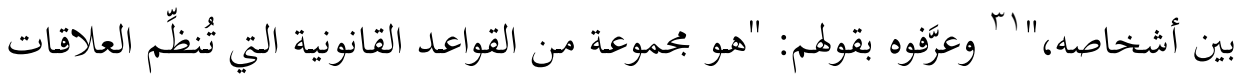

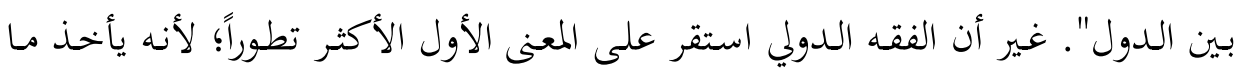

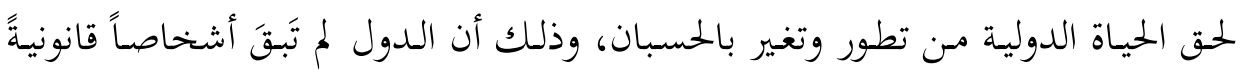

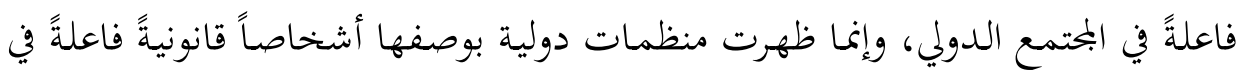

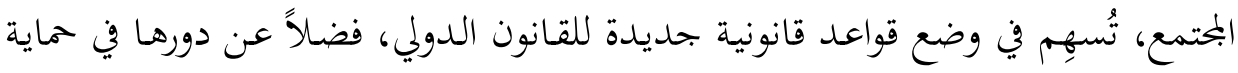

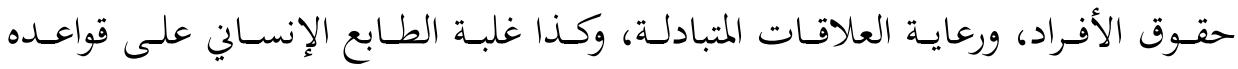

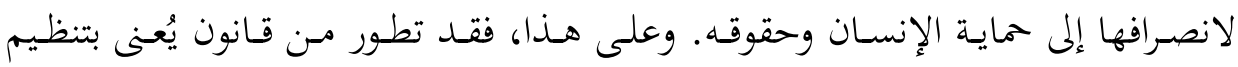

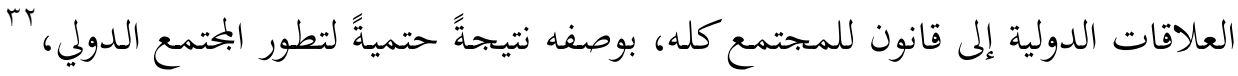
في إشارة إلى هذا التطور.

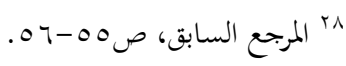

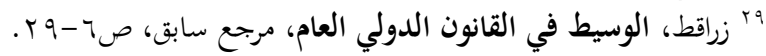

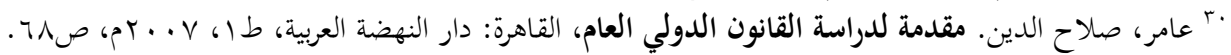

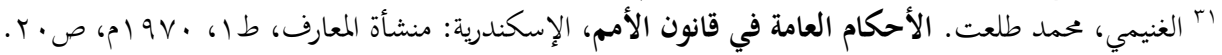

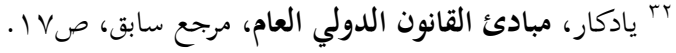




\section{ب. تطور مجالات تطبيق القانون الدولي المعاصر:}

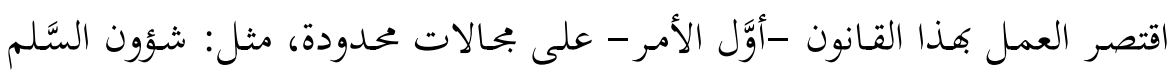

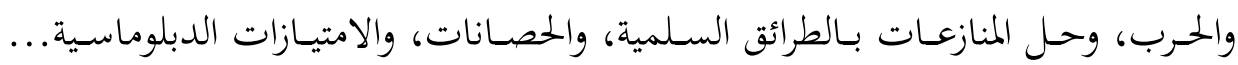

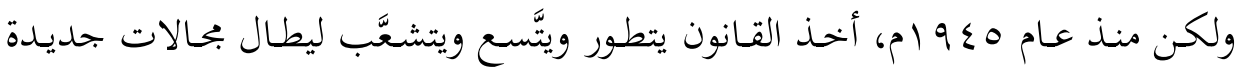

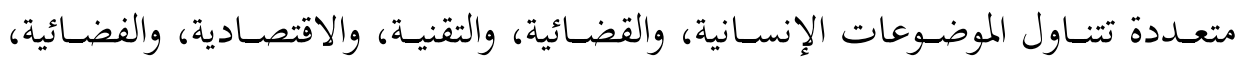

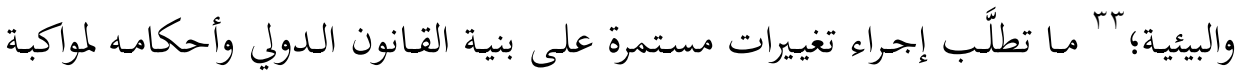

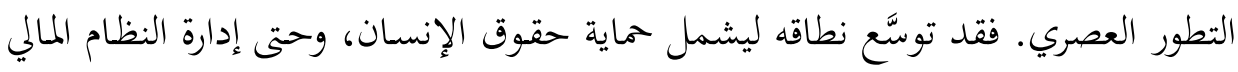

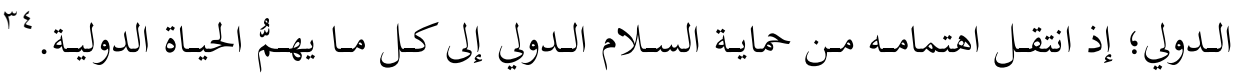

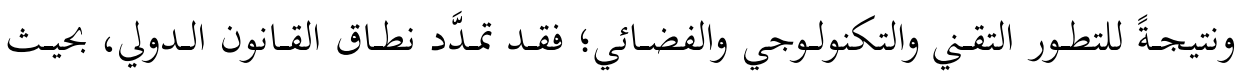

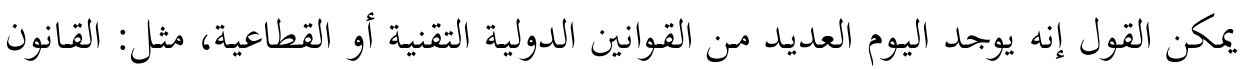

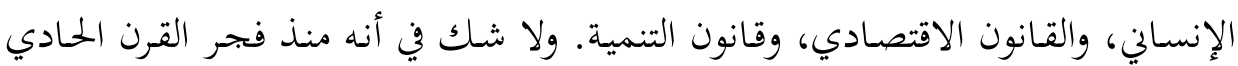

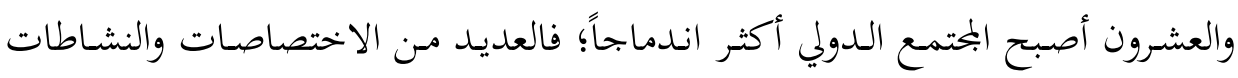

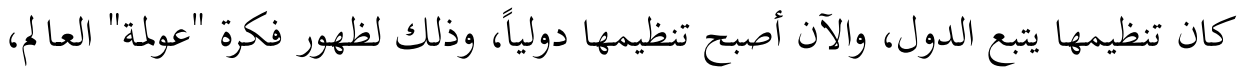

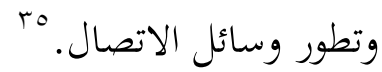

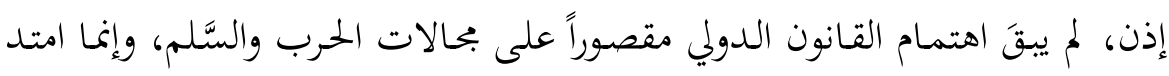

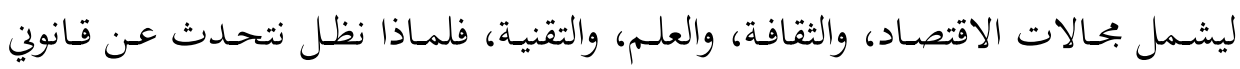

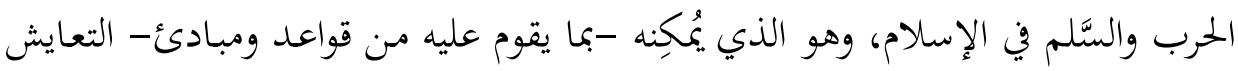

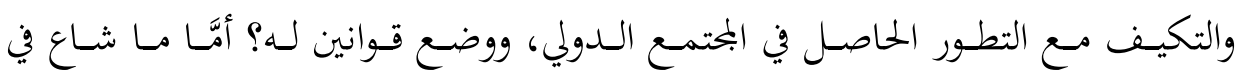

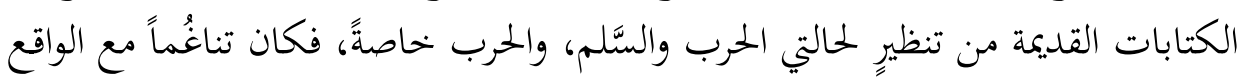

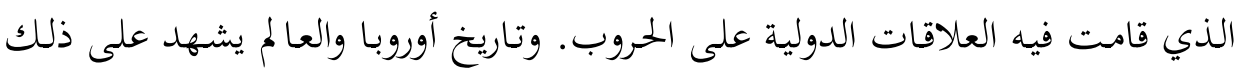

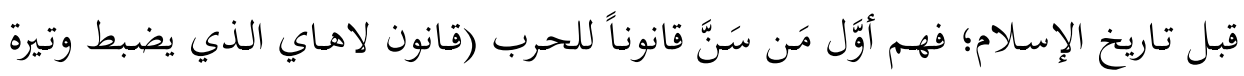

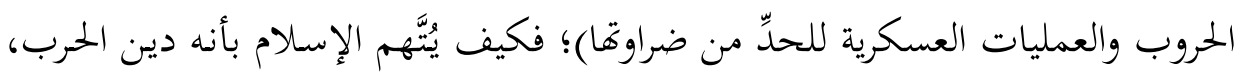
والحرب فيه عادلة ناشرة للخير والعدل لا الظلم.

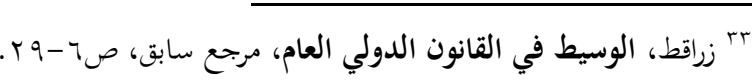

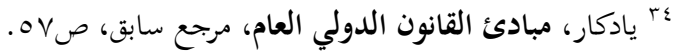

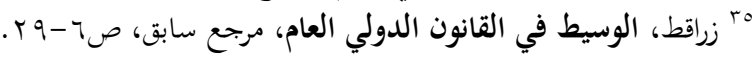


ونتيجةً لمذا الواقع الدموي، وضراوة الحروب التي شهدها العالم؛ فقد تطورت مطالب

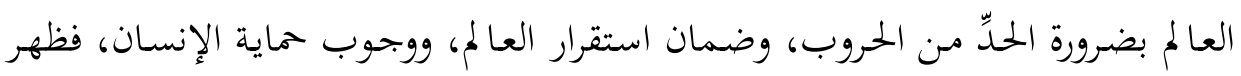

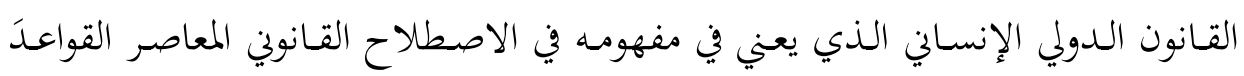

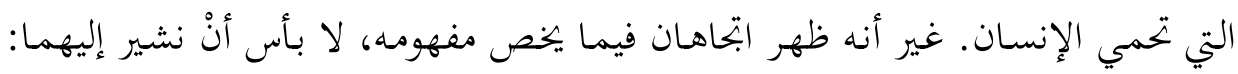

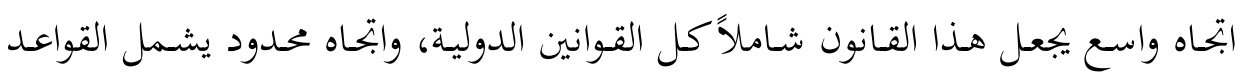

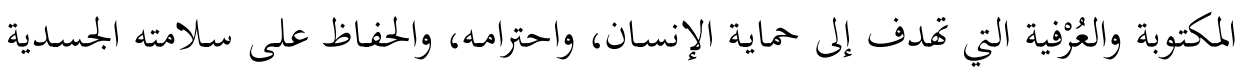

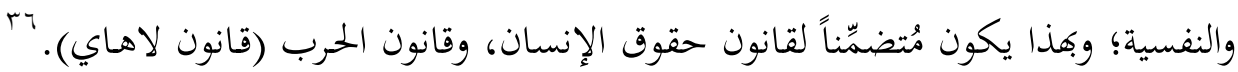

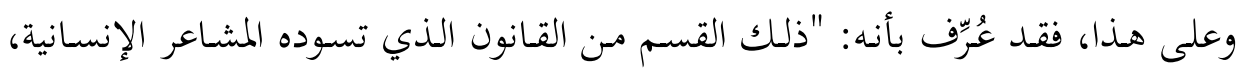
ويهدف لحماية الإنسان."

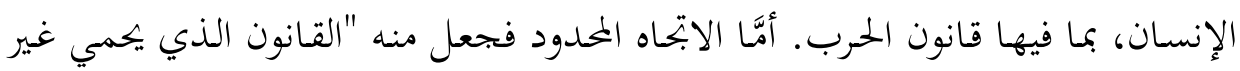
المقاتلين أثناء النزاعات المسلحة، فيهتم بحماية العسكريين من غير المقاتلين، أو من خحارج

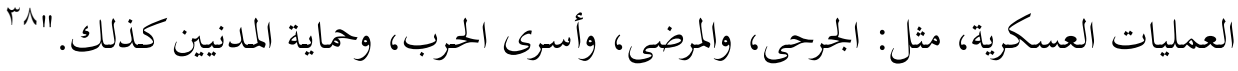

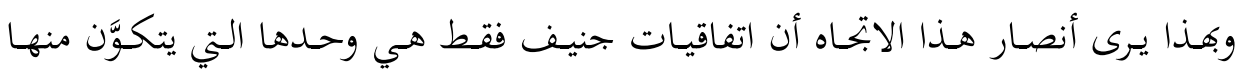

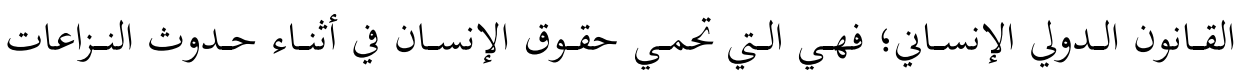

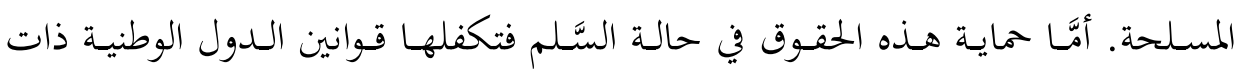
الكيانات المستقلة عن القانون الدولي العام بفروعه المختلفة. والمعتى الراجح المعتمـد عنــ الكثيرين للقـانون الـدولي الإنسـاني هـو : "بحموعـة مـن القواعد القانونية الدولية التي هتم بحماية الإنسان وقت الحروب والنزاعات المسلحة، والتي

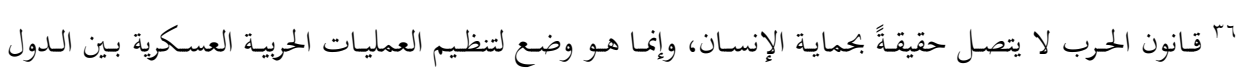

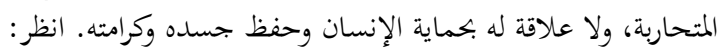

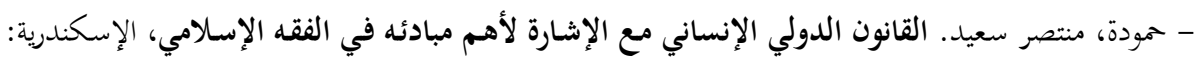

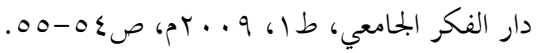

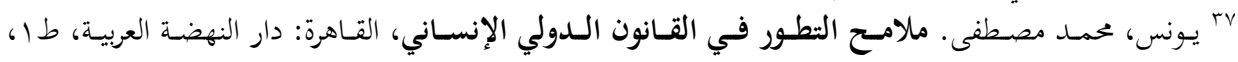

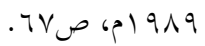

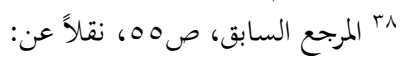

- J. s. pictât, les principes du droit international humanitaire, CICR, Genova, 1966, p.7. ara مودة، القانون الدولي الإنساني مع الإشارة لأهم مبادئه في الفقه الإسلامي، مرجع سابق، صه. 
وردت في اتفاقيات جنيف والبروتوكولين الملحقين بها." ·ـ أمَّا تطبيقه فيكون وقت الحروب والنزاعات المسلحة؛ سواء أكانت دولية، أم غير دولية.

\section{r ـ مفهوم "القانون الدولي الإسلامي" بين التاريخ والواقع:}

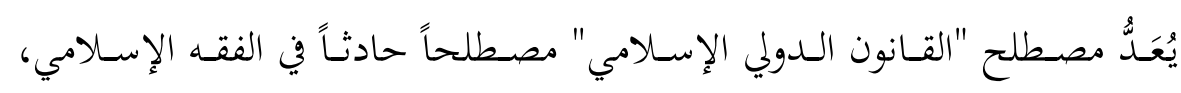
ولكن ذلك لا ينفي وجود قانون دولي في الإسالام؛ إذ إن تعاليمه تشمل المجالات جميعاً، وهذا ما سيتبيَّن من خلال هذا العرض.

\section{أ. مفهوم "القانون الدولي الإسلامي": - أل}

إن مقصسود العلمـاء بـالعلاقات الدوليـة في الإسـلام هـو القـانون الـدولي الإسـلامي بالمصـطلح الحـديث، والـمُتحدَّث عنـه حـتى السـاعة ومـا ظهر في الدراسـات المقارنـة هـو القانون الدولي الإسلامي العام، والقانون الدولي الإسالهي الإنساني، والأشهر هو القانون العـام، وقـد كتـب فيـه الأقـدمون ضـمن موضـوع السِّير، والمهـاد، والمغــازي .... وأشهرها

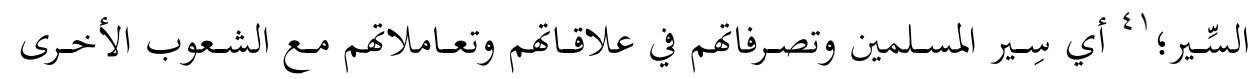
(المشـركون مـن أهـل الحـرب (أي الحربيـون)، وأهـل العهـــ، ومــهـم الـمُستأمَنون، وأهـل

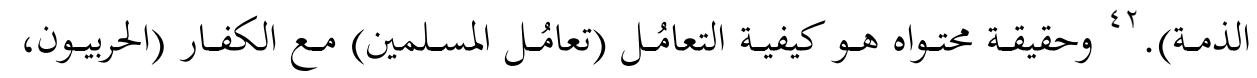
والذميون، والمعاهدون، والمُستأمَنون)، وهذا يشمل التعائل مع الأفراد والدول، في حالتي

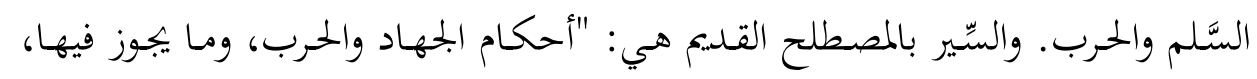
ومـا لا يجـوز، وأحكام الصـلح والموادعات، وأحكام الأمـان ومـن يجـوز، وأحكام الغنـائم والفديـة والاسـترقاق وغـير ذلك ... محـا يكـون في الحـروب وأعقابهـا، فهـو بـاب تنظيم العلاقات الدولية بين المسلمين وغير المسلمين في السَّلم والحـرب، وإنْ كان أكثر الكالام

$$
\text { . }
$$

اء الفرا، محمد سليمان نصر الله. "أحكام القانون الدولي الإنساني في الإسلام"، (رسالة ماجستير، الجحامعة الإسلامية،

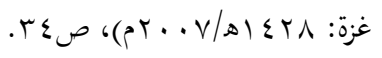

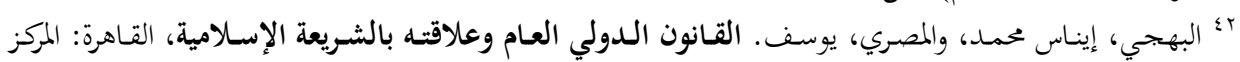

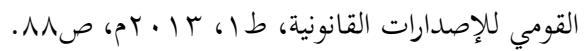




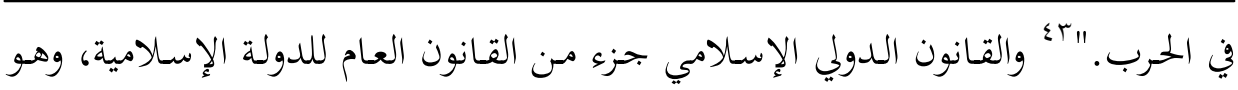
الشريعة الإسلامية؛ لذا فإنان قوة القانون الدولي الإسلامي مستمدة مـن قوة قواعـد هـا

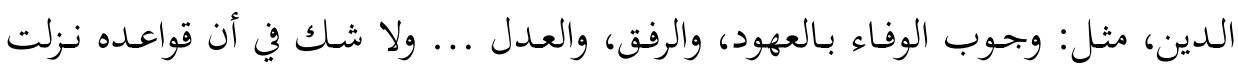

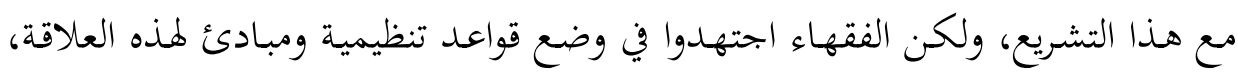

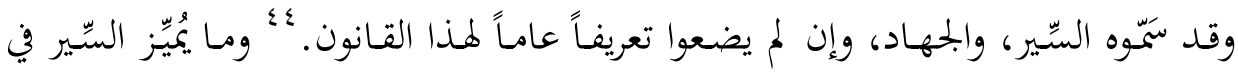

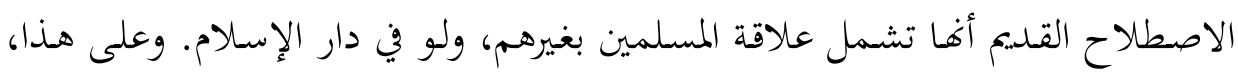

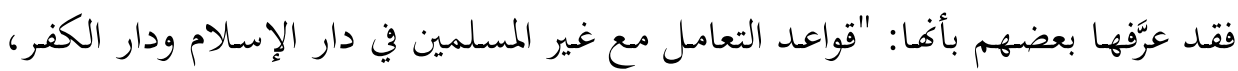

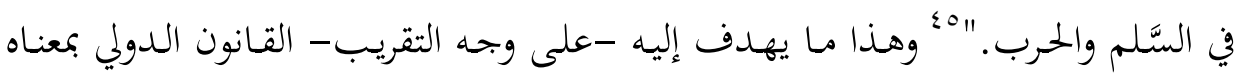
الحديث.

إذن، فهو يعني أحكام العلاقات الدولية في حالتي الحرب والسَّلم، ومن تعريفاته: - "هو القواعد والأحكام الشرعية التي تحكم علاقات الدولة الإسـلامية مع غيرها

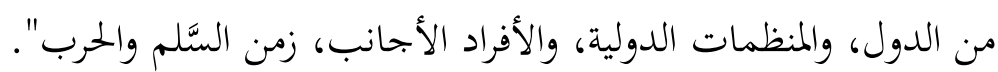
- "هو القواعد والأحكام الشرعية التي تُنظّم العلاقات الدولية بين المسلمين، وغير

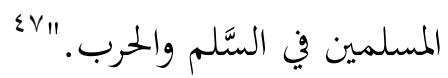

- "طريقة معاملة المسلمين لغيرهـ؛ سواء كانوا مسالمين، أو محاربين أفراداً أو دولاً،

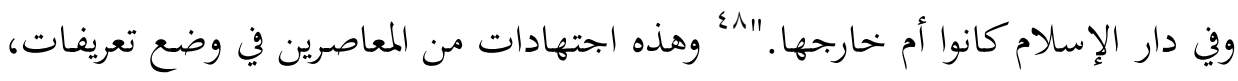
بعضها فيه محاكاة للقانون الدولي، وبعضها الآخر مُخالفاً لذلك.

rأ ضمرية، عثمان. أصول العلاقات الدولية في فقه الإمام محمد بن الحسن الحسن الثيباني: دراسة فقهية مقارنة،

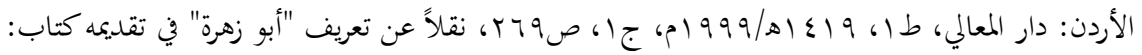

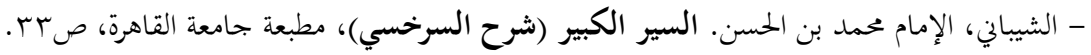

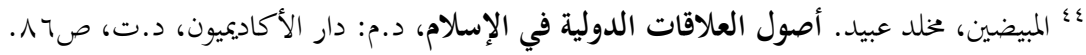

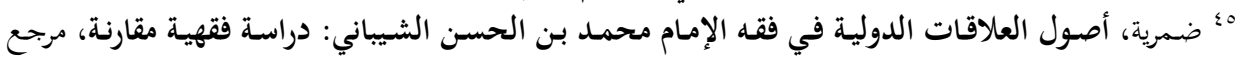

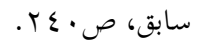

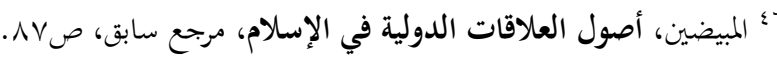

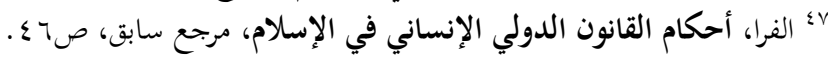

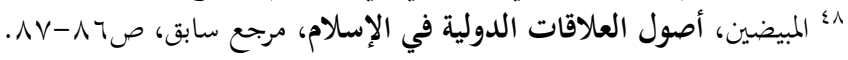


وإذا أنعمنا النظر في تعاليم الإسلام وتشريعاته وقوانينه، فإننا بجدها تعترف بالأجنبي،

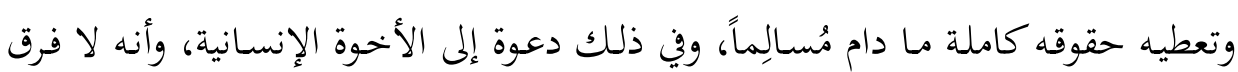

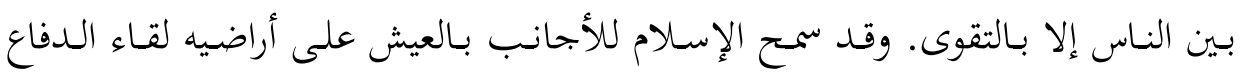

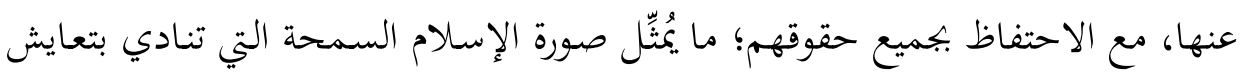

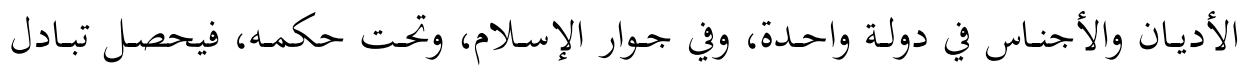

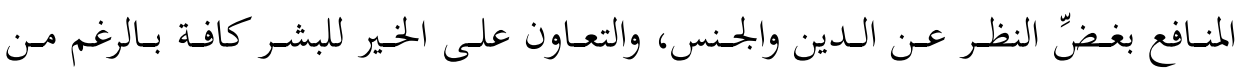

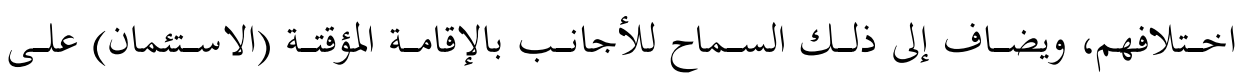

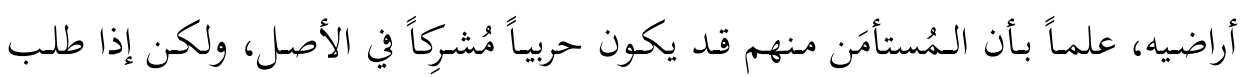

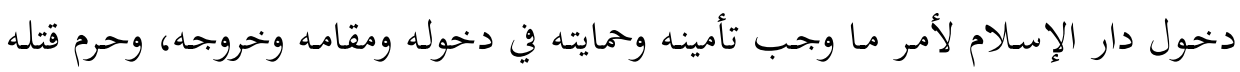

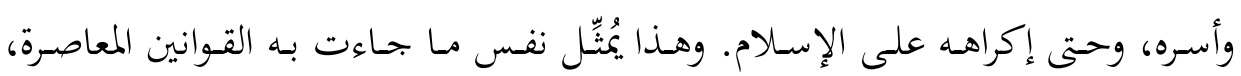

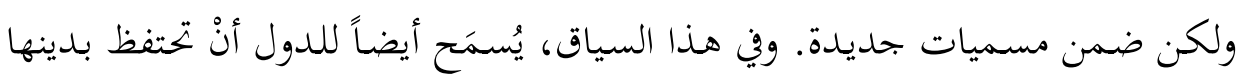

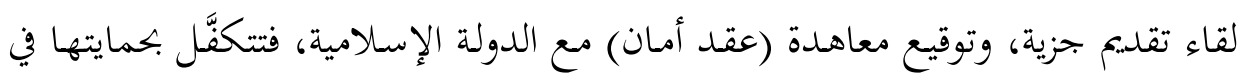

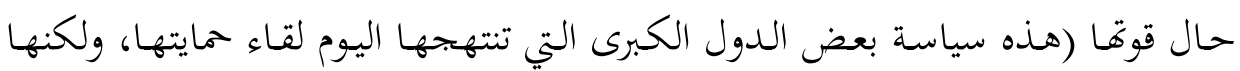
تشترط تقديم تنازلات مقابل الحماية، وشتّان ما بين الحمايتين). وهذا كله يُؤَّد سماحة الإسلام، ودعوته إلى هذا النوع من التعارف، وصون الأنفس

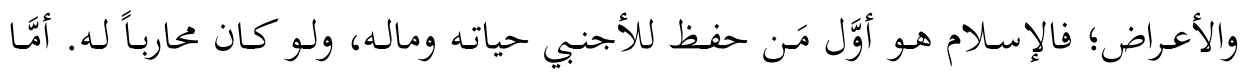

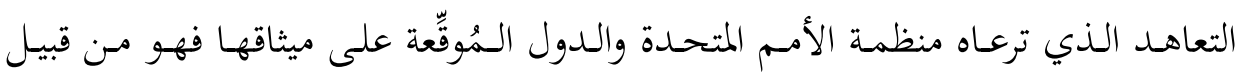

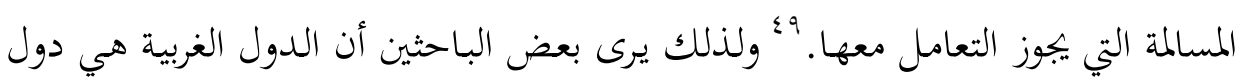

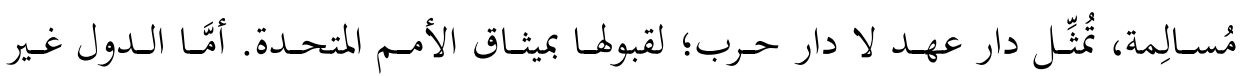

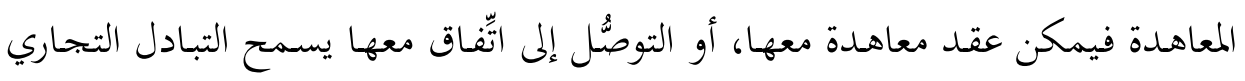
والاقتصادي والثقافي والأمني.

فالتقسيم القـديم للدول في الفقـه الإسلامي مقبول في معنـاه، ولكن يجـب تغييره في

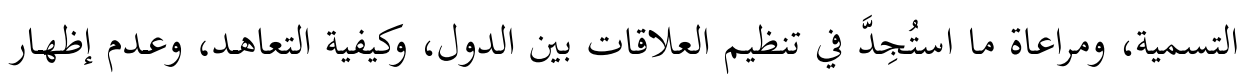


العداوة، والالتزام بالسـلام. وفيما يخص مصطلح "دار الإسلام" القـديم الذي كان يعني

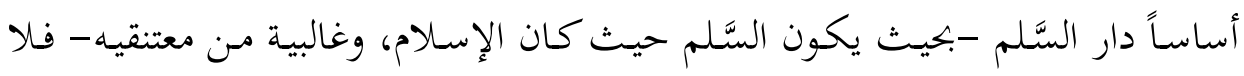
يوجد اليوم دار سلام حقيقةً، وهي -تعني في حقيقتها- دار العدل التي يتمتع فيها الناس

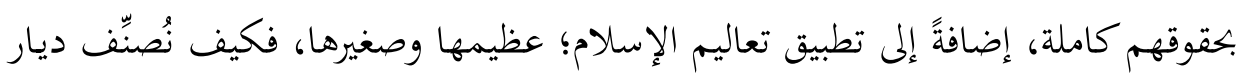

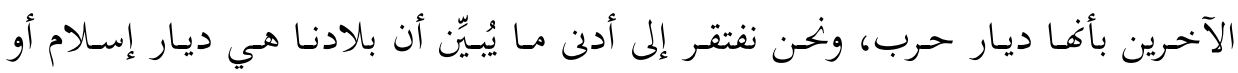

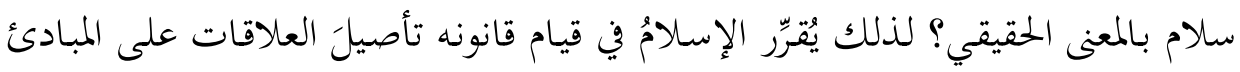

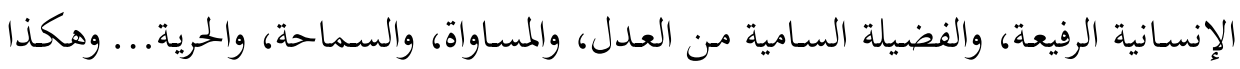

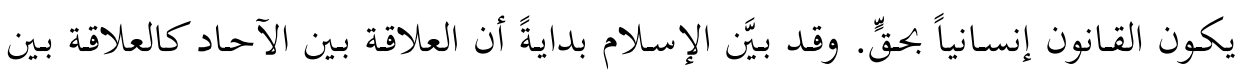

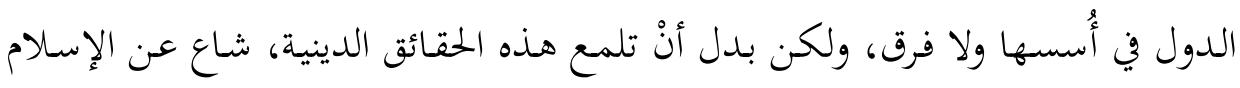

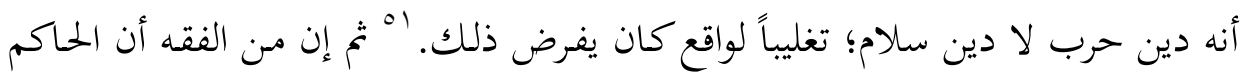

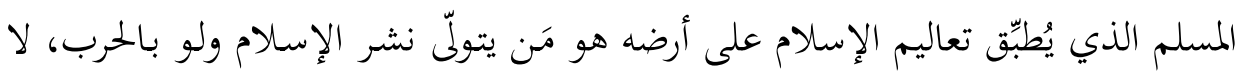

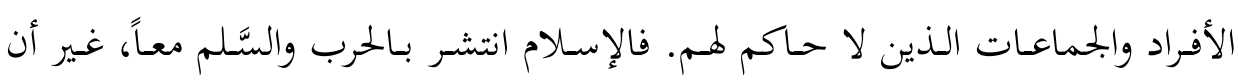

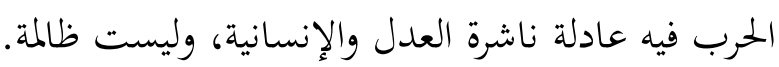

أمَّا مصـطلح "القـانون الـدولي الإسـلامي" فهـو مصـطلح حـادث في الفقـه الـدولي

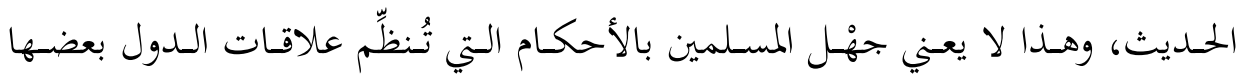

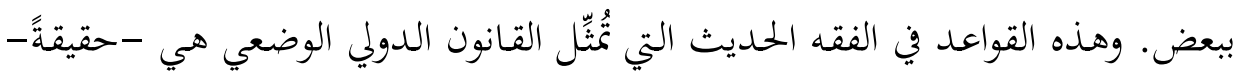

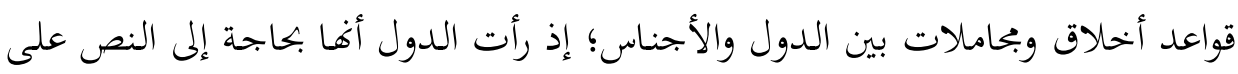

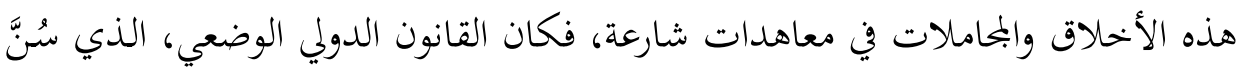

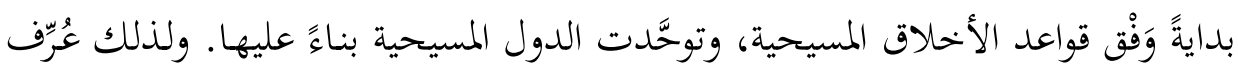

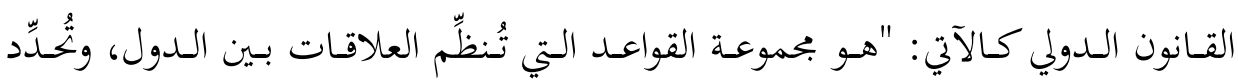

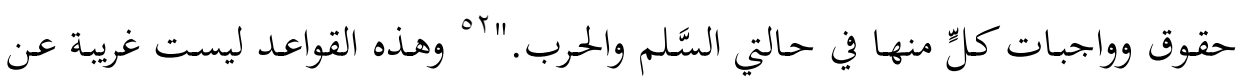

ان أبو زهرة، محمد. العلاقات الدولية في الإسلام، القاهرة: دار الفكر العربي، 10 إهـ/9901م) صب؟ـ-00. ror

- منصور، علي علي. الشريعة الإسلامية والقانون الدولي العام، القاهرة: البحلس الأعلى للشؤون الإسلامية، .

- البهجي، القانون الدولي العام وعلاقته بالشريعة الإسلامية، مرجع سابق، ص1 1 . 


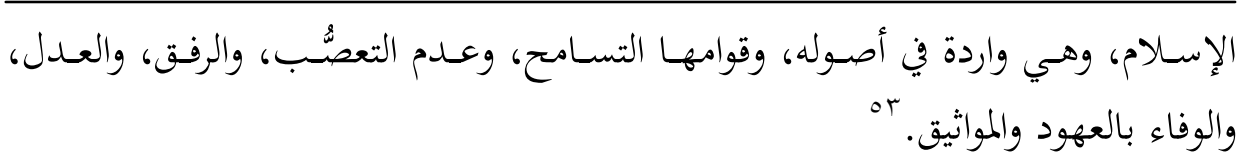

\section{ب. مفهوم "القانون الدولي الإنساني الإسلامي":}

مصطلح "القـانون الدولي الإنساني الإسلامي" هـو أيضاً مصطلح حسادث في الفقه

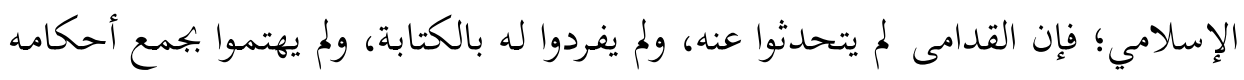

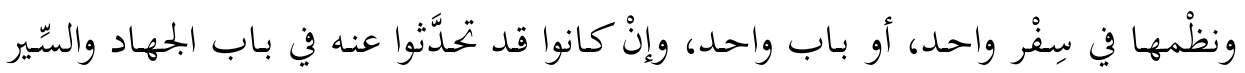

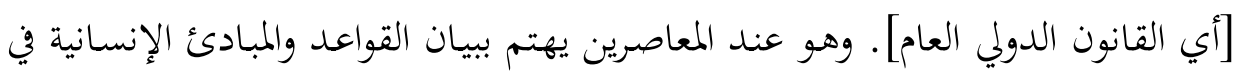

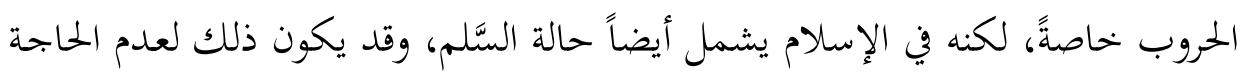
إلى التذكير بهذه المبادئ، ولا سيما في قانوننا الإسلامي.

ويُعْزى ذيوعه اليوم على نحوِ لافت إلى الاهتمام الزائد بحقوق الإنسان، والمطالبة بها

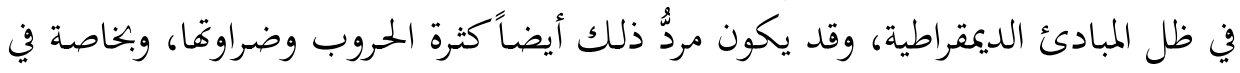

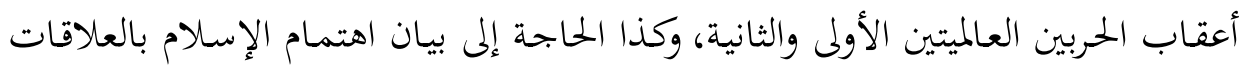

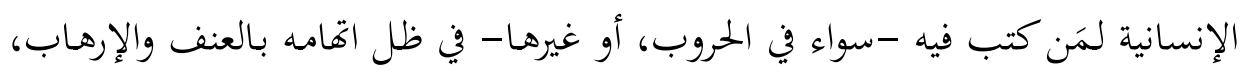

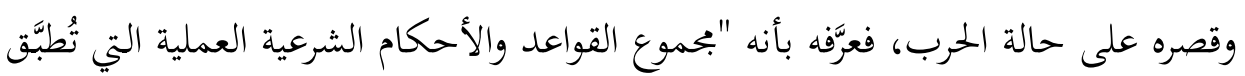

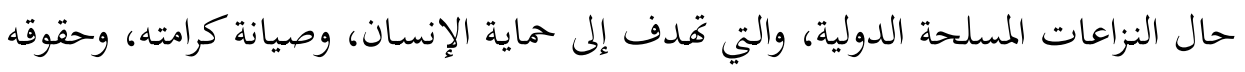

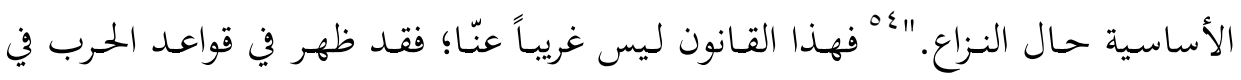

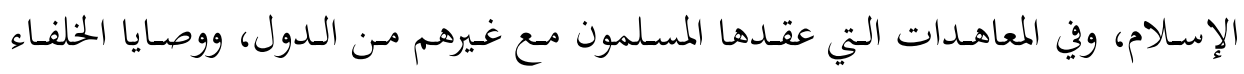

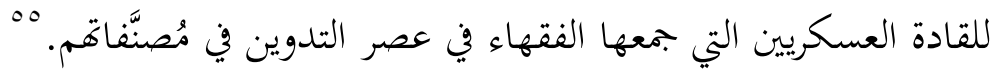

وبغضِّ النظر عمَّا إذا كان يُقصَّد به القانون الخاص في زمن الحرب، فإن في الإسلام

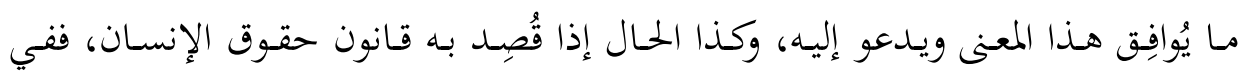

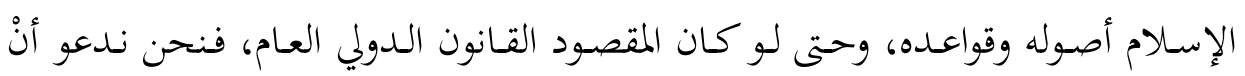

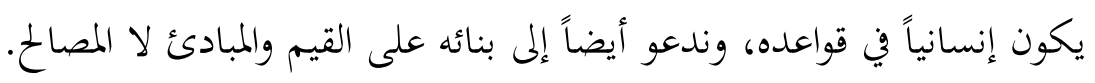

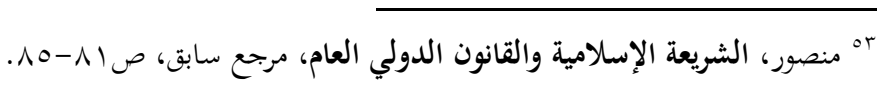

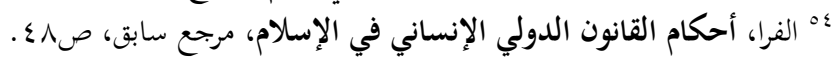

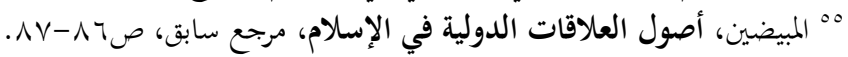




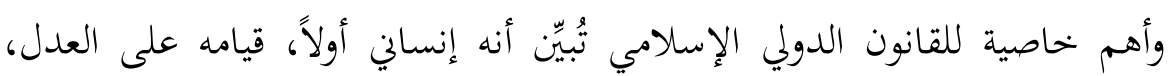

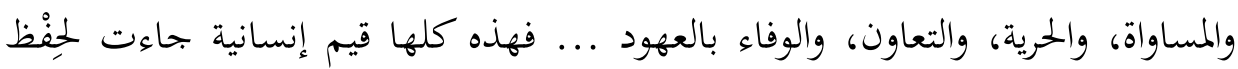

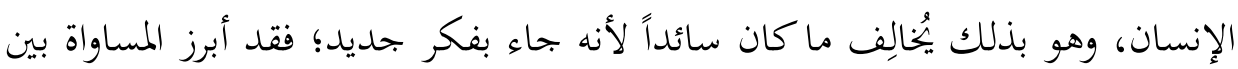

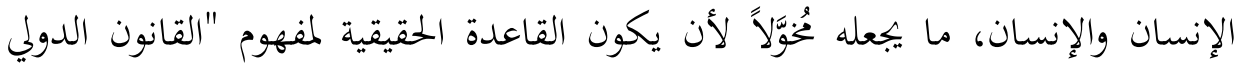

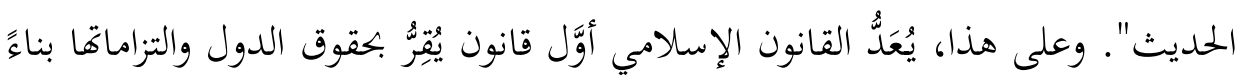

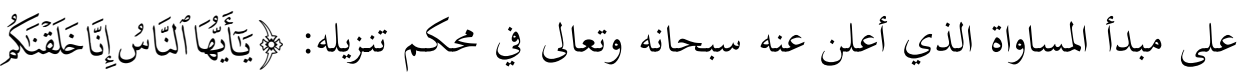

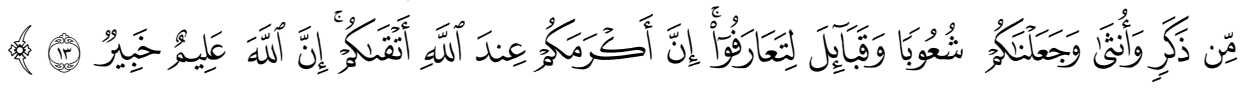

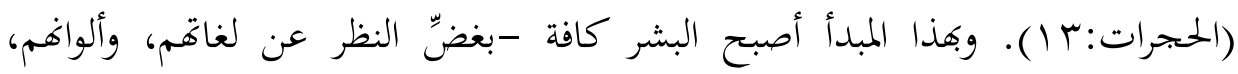

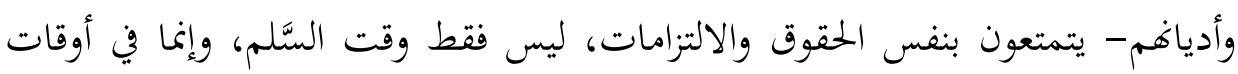

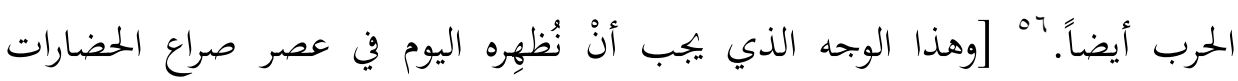

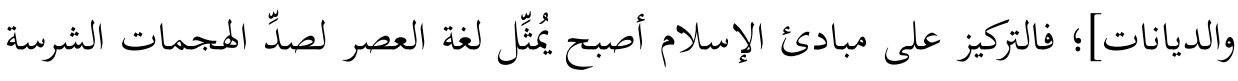

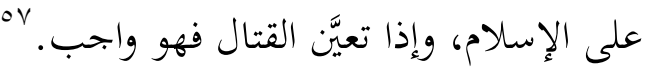

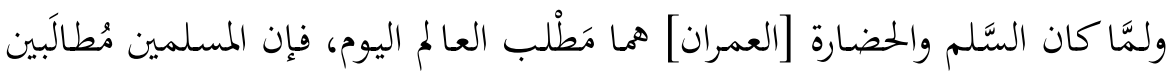

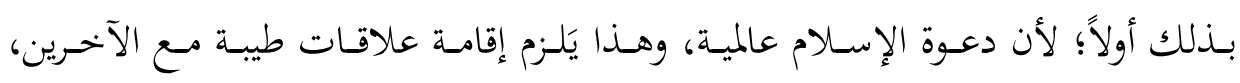

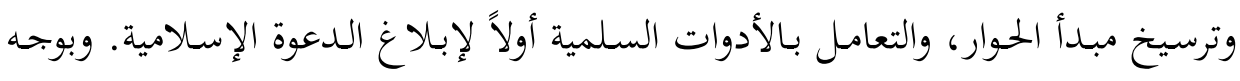

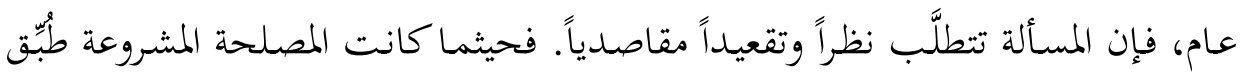

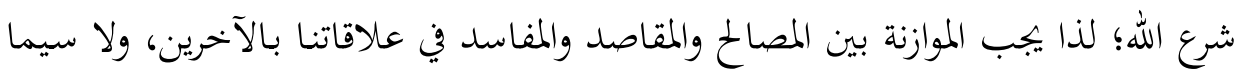

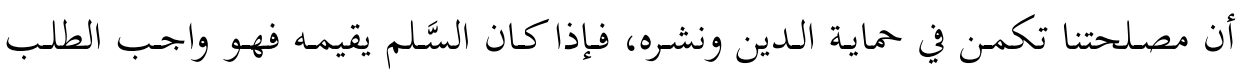

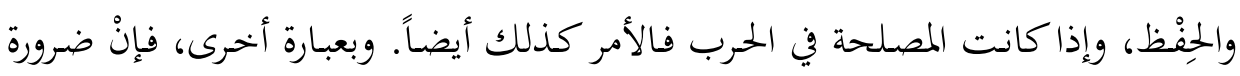
فضرورة، وإنْ حاجة فحاجة، وإنْ تكميل فتكميل. والشيء نفسه ينطبق على التعارف؛ إذ يكون بحسب القصد منه، ومدى إسهامه في

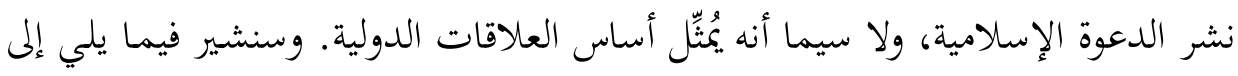

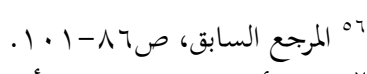
لاه شتا، أمداعد عبد الونيس. الأصول العامة للعلاقات الدولية في الإسلام وقت السلم، القاهرة: المعهد العلمي

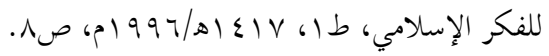


درجة القصد إليه، وكيف يُعتبَر ويُصنَّف وَفْقها؛ فقد يكون في مرتبة الضرورة، أو الحاجة، أو التحسين.

إن دعـوة الإسـلام إلى التعـارف دليـل على اهتمامـه بقيـام حضـارة الإنسـان وإعمـار الأرض، وهـا لا يقتصر فقط على المسلم؛ فالهدف هو بنـاء حضارة إنسانية، وفي حال وُجِحد أيٌّ اختلاف، فإنه يكون وسيلة للتعارف لا العكس؛ فالاختلاف واقع، وهو سبيل

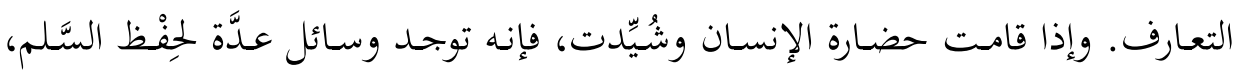
مثـل : التعاهـد، والتحــالف، والصـلح؛ وذلـك أن مـن مقاصــ الشـريعة الإسـالامية حِفْظظ الأنفس وإحياءها، وليست نفس المؤمن فقط هي المقصودة.

\section{ثالثاً: حقيقة التعارف وأُسسه الداعمة للعلاقات الدولية}

تعوَّفنا فيما سبق أن القانون الدولي الإسالامي عام لجميع العلاقات الدولية (إنسانية،

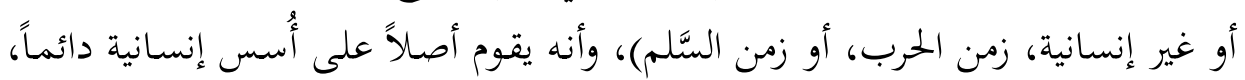
بغضٍ النظر عن الاختلاف؛ لذا كان للتعارف أثره الواضح في هذه العلاقات. فما معنى

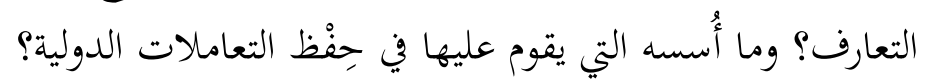

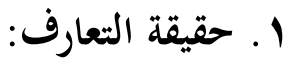

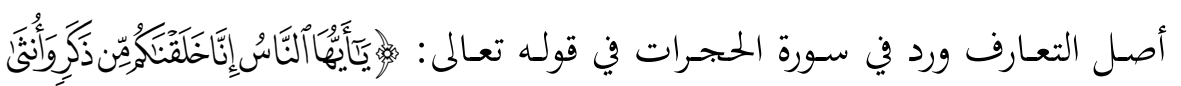

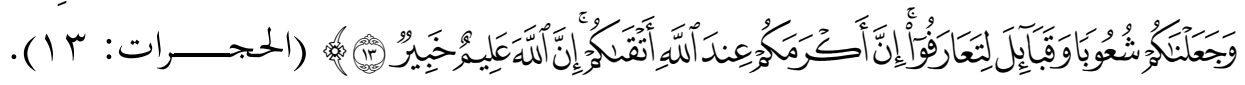
وهي التي قال فيها سيد قطب: "سورة تبدو كأفا تكاد تستقل بوضع معا لم كاملة لعالم رفيع كريم نظيف سليم، منظمة القواعد والأصول والمبادئ والمناهج التي يقوم عليها هذا

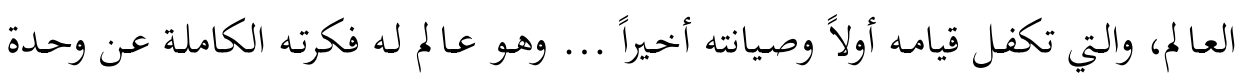
الإنسانية المختلفـة الأجناس المتعددة الشعوب، وله ميزانه الواحد الذي يقوم بـه الجميع،

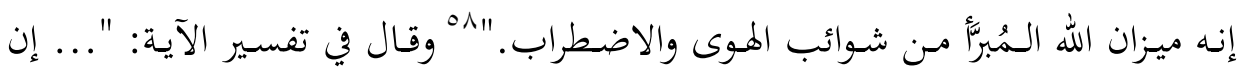
التعارف هـو غاية خلق الله للنـاس شعوباً وقبائلَ، وليس للتنـاحر والخصام، إنما للتعارف

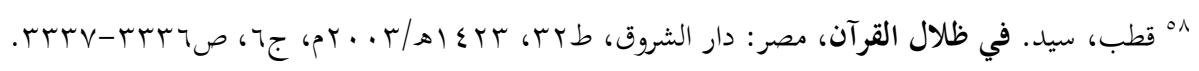


والوئام، فأمَّا اختلاف الألسنة والألوان، واختلاف الطبائع والأخلاق، واختلاف المواهب

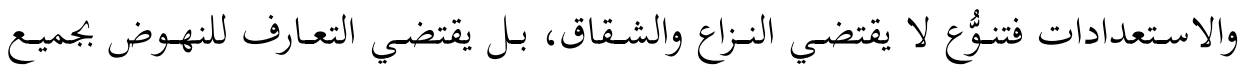

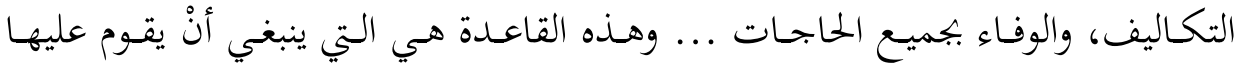

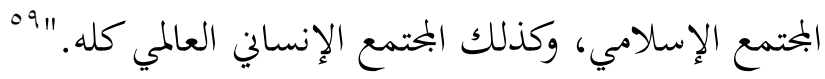

فمقصد التعارف هو سبيل الوحدة الإنسانية من دون تناحر، والمساواة بين أجناس

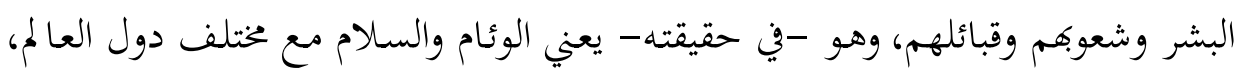

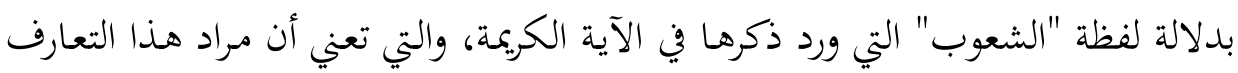

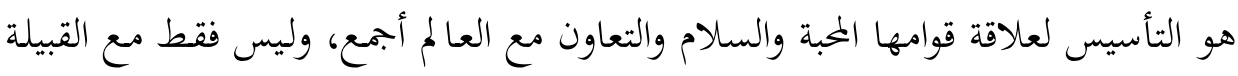

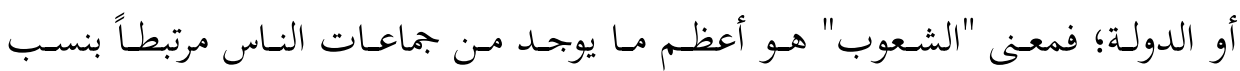

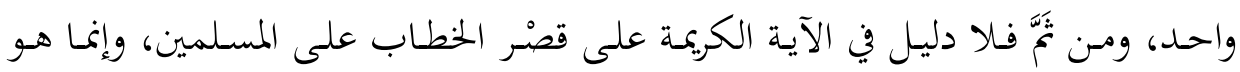

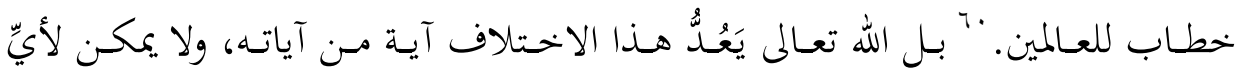

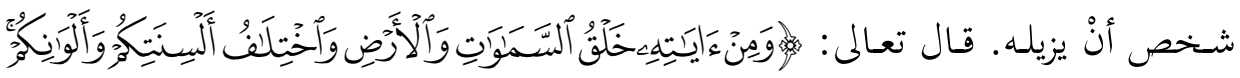

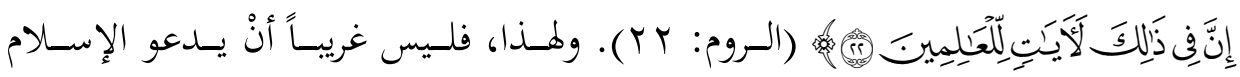

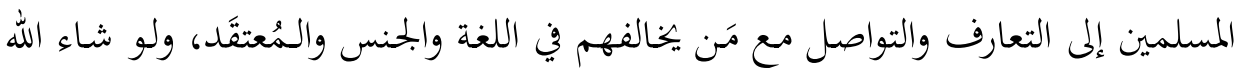

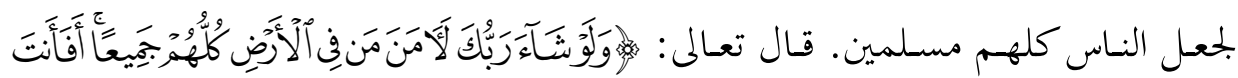

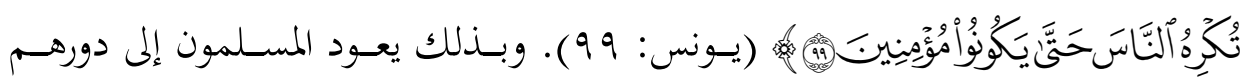

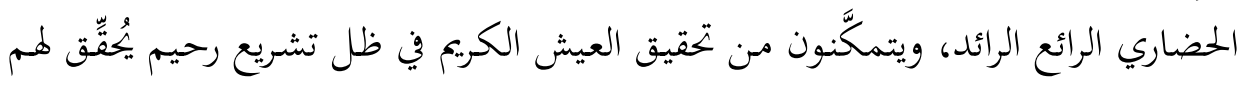

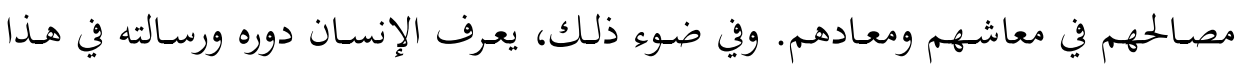

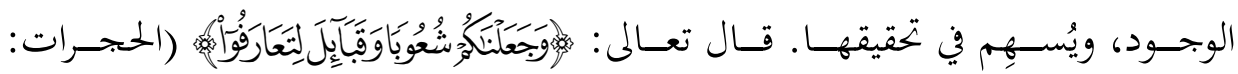
. (1) إذن، للتعارف أثره في إنشاء بحتمع فاضل (إنساني في ظل التنوُّع والحرية)، وهو -في

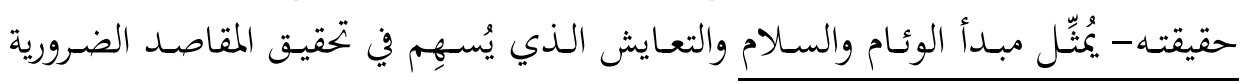

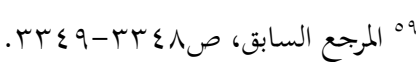

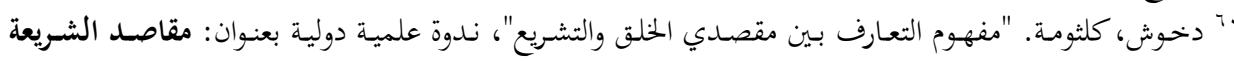

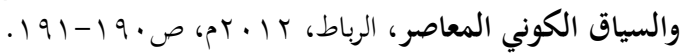

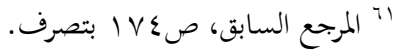




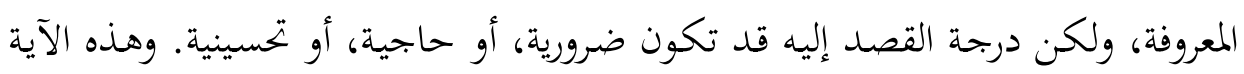

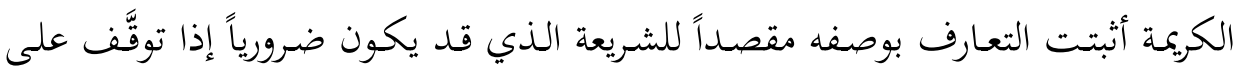

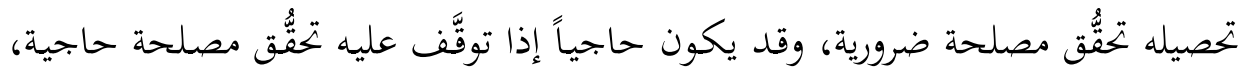
وقد يكون تحسينياً إذا كان له أثره في قِوام الأُمة.

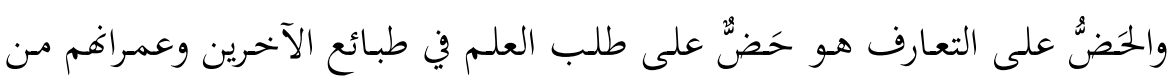

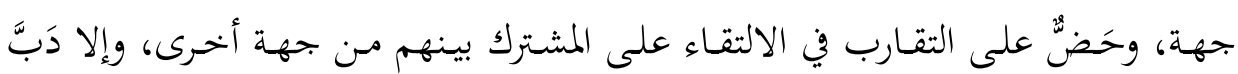

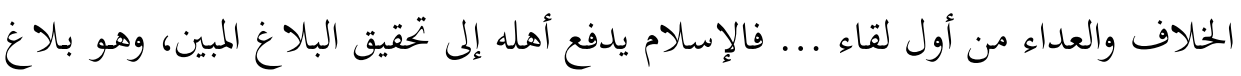

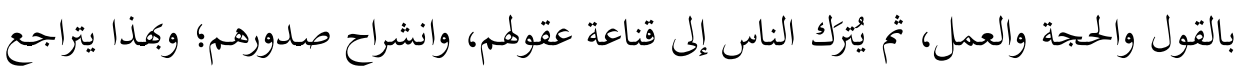

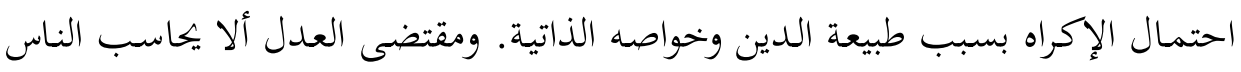

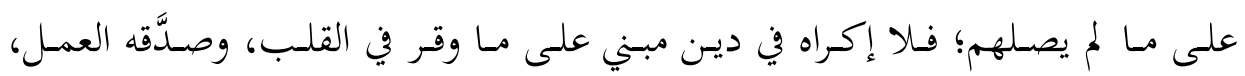

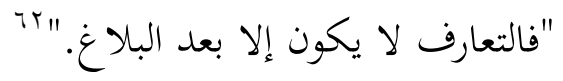

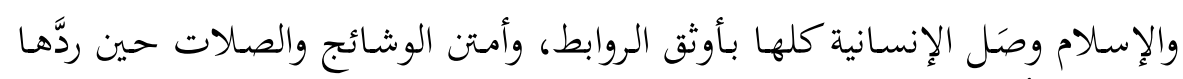

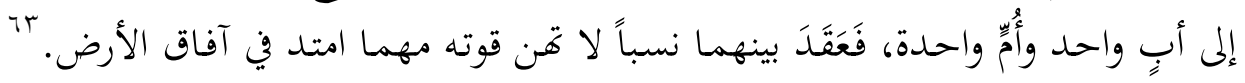

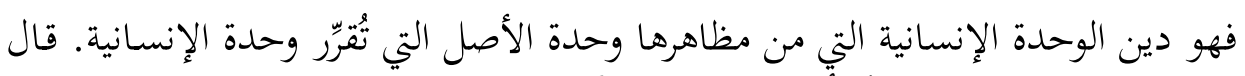

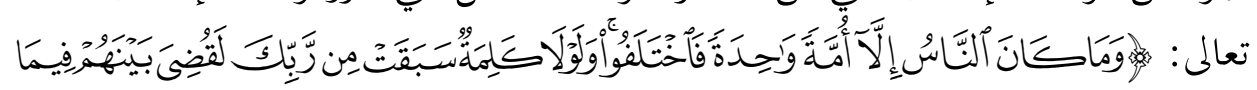

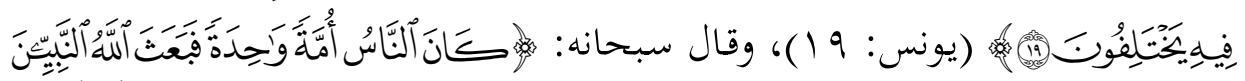

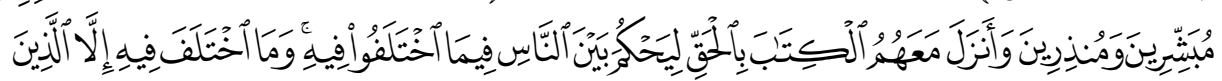

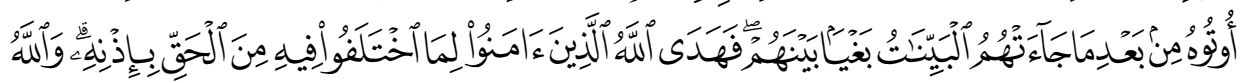

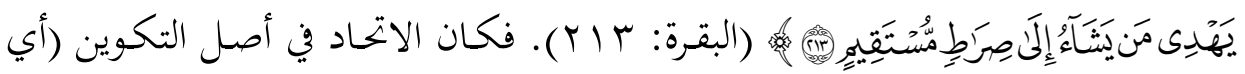

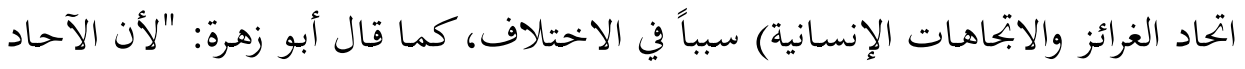

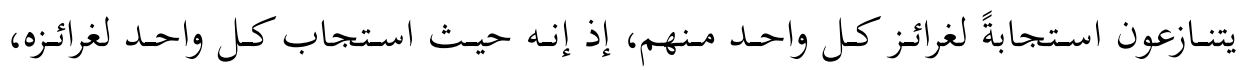

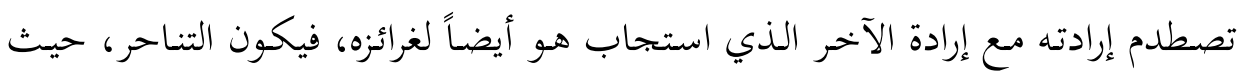

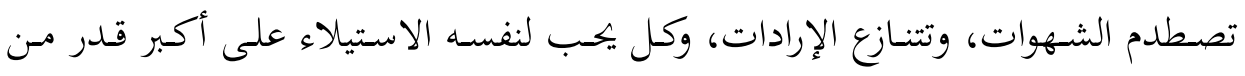

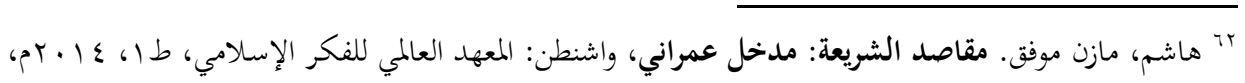

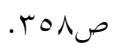

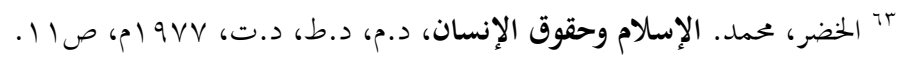




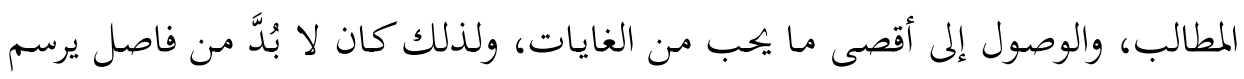

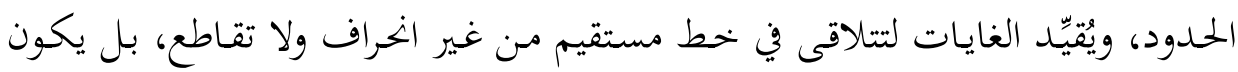

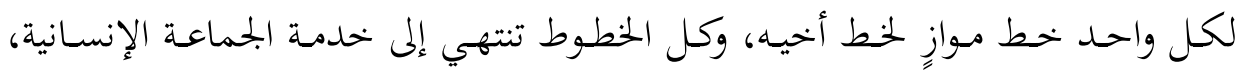

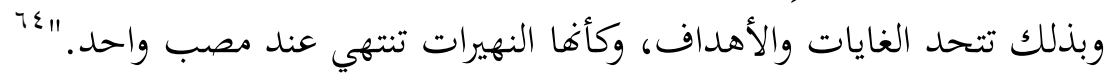

وهكذا استنتج أبو زهرة أن اتحاد الغرائز هو سبب في التفرُق، وأن اختلاف الألسنة

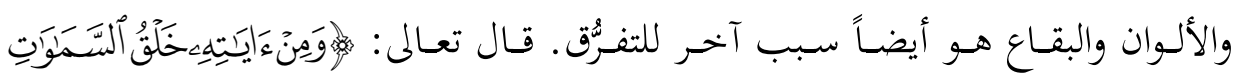

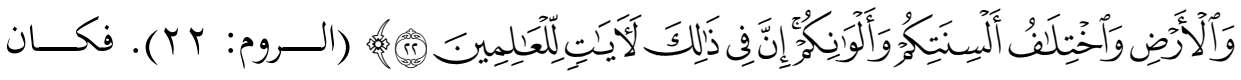

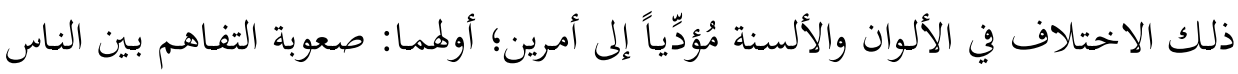

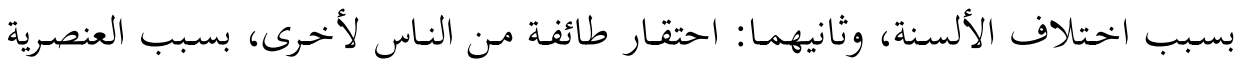

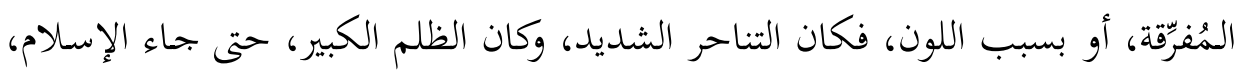

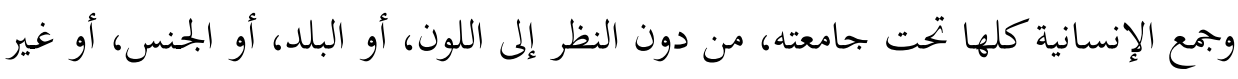

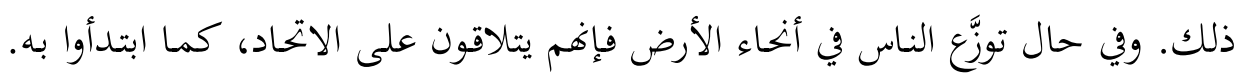

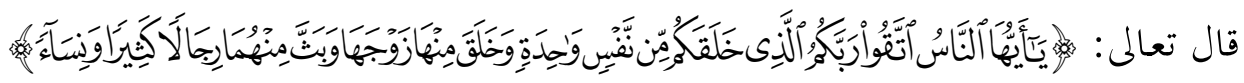

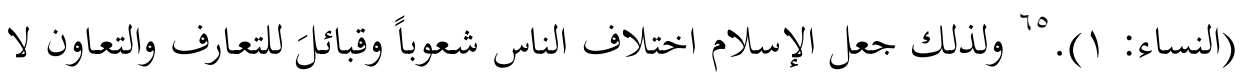

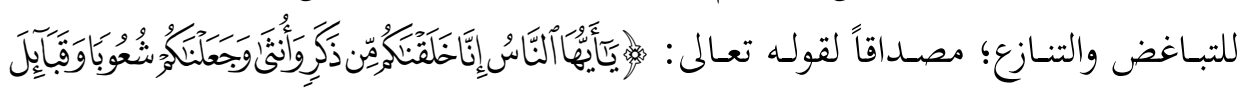

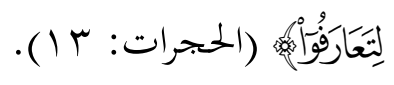

إذن، فالتنوُع في المخلوقات مَدْعاة للتعارف والتعاون، غير أن للإسلام نظرته الحناصة

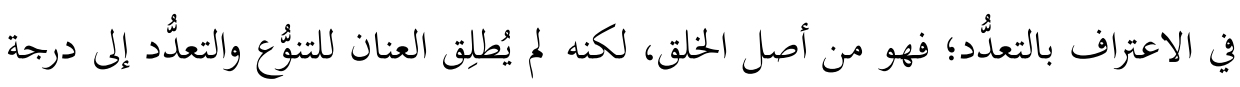

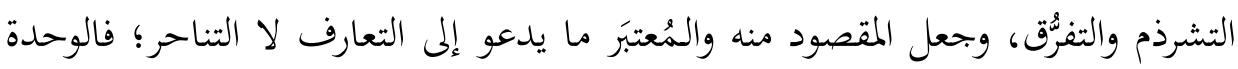

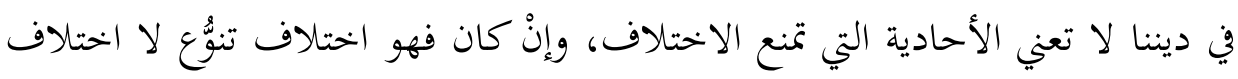

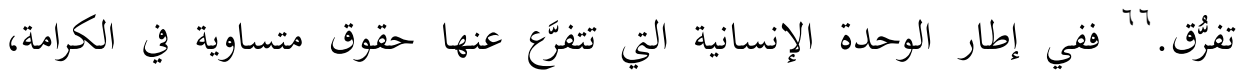

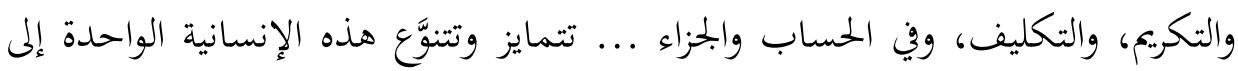

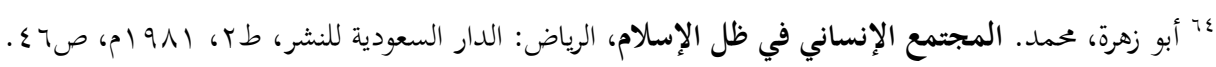

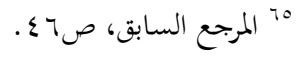

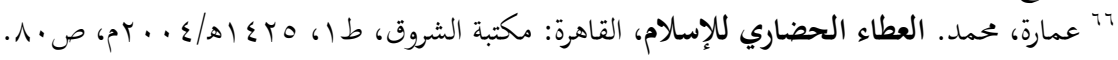


شعوب، وقبائل، وأمم، وأفراد، وإلى ألوان، وأجناس، وألبسة، ولغات، وحضارات...

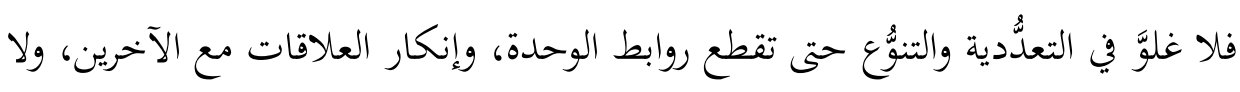

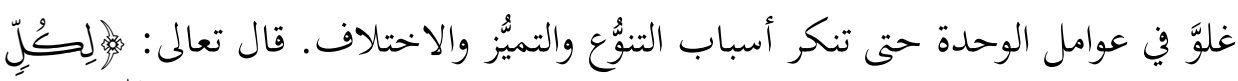

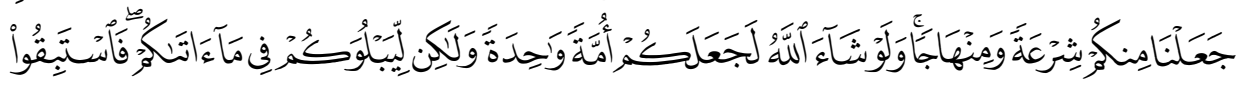

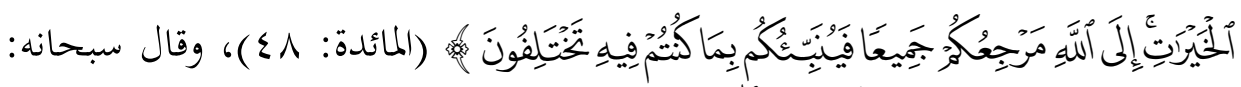

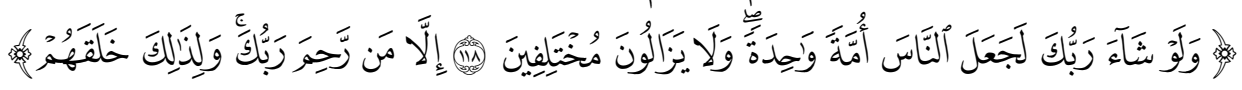
(1) (1) (هود:11)

فالإنسانية بكثرة أفرادها وشعوبها وقبائلها يجـب أنْ تكون مَذْعاة للتعارف والتعاون

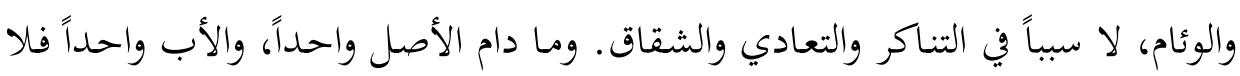

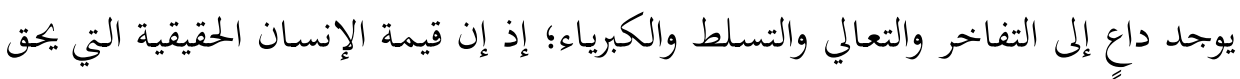

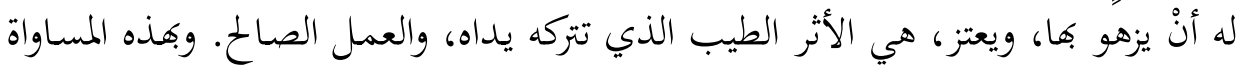

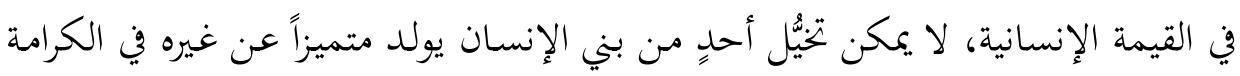

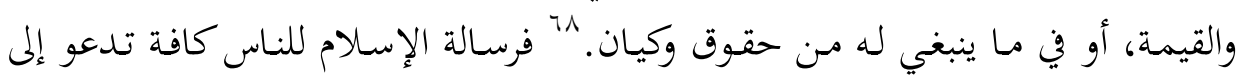

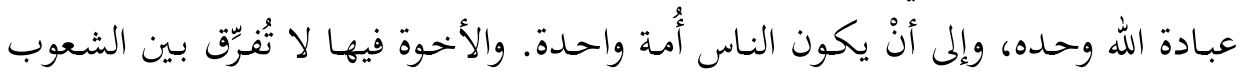

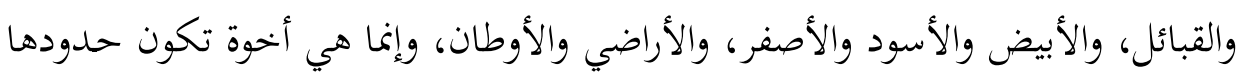

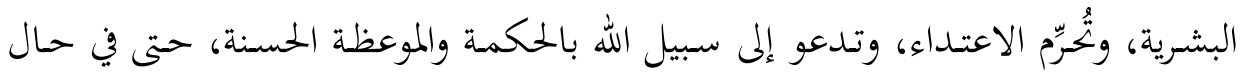

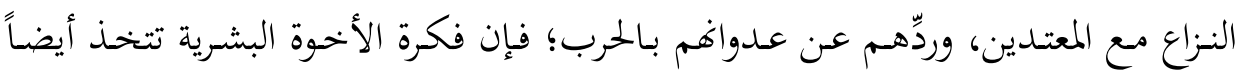

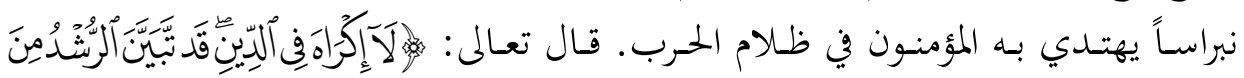

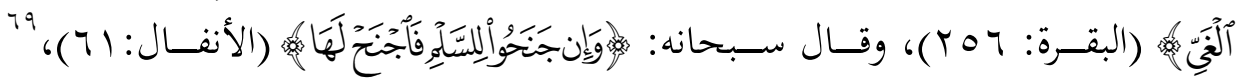

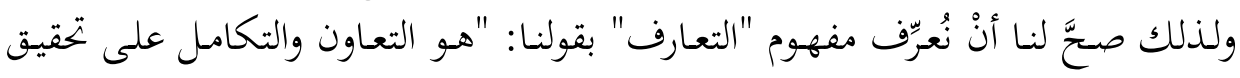

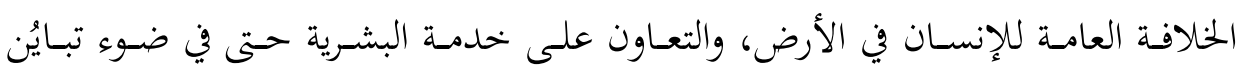

$$
\text { العقائد والأخلاق. }
$$

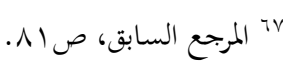

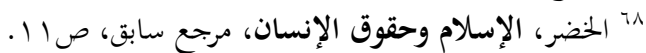

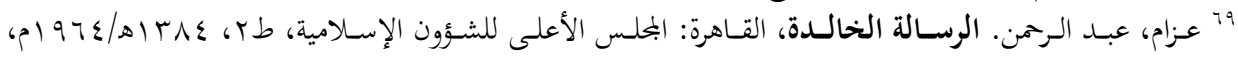




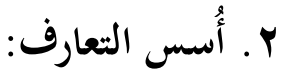

يتبيَّن مََّّا سبق وجود مقصدينِ من إقامة العلاقات الدولية، هما: نشر الإسلام بوصفه

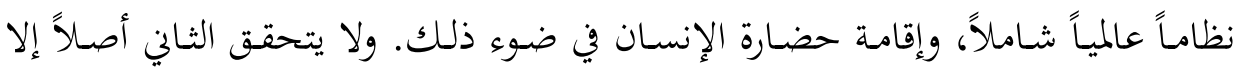

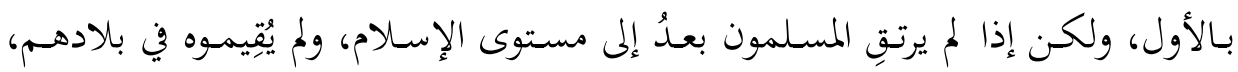

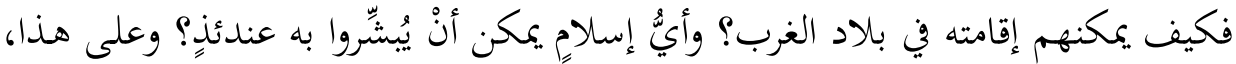

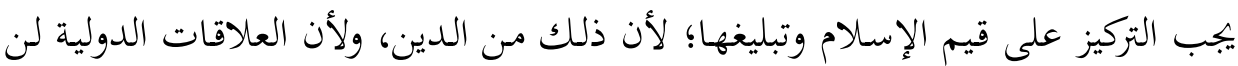

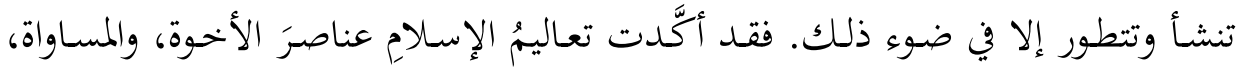

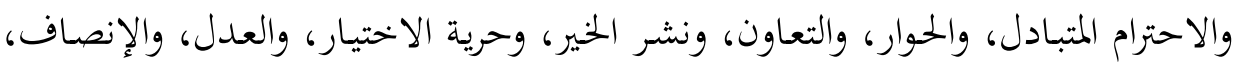

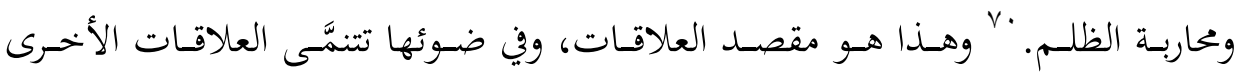
الاقتصادية والسياسية الطيبة بين أفراد المجتمع الإنساني الواحد. وضعفنا اليوم يُحتِّم علينا إقامـة علاقات ودية مع مختلف دول العالم؛ سواء كانت

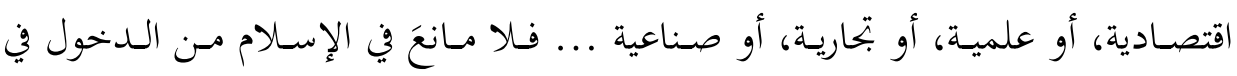
مبادلات اقتصادية وبتحارية مع غير المسلمين؛ استيراداً وتصديراً بحسب الضرورة أو الحاجة إنة

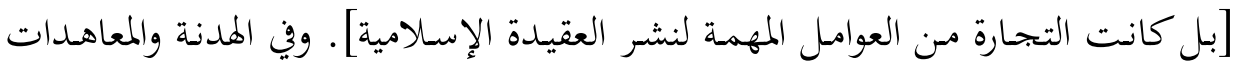
تنتعش أيضاً العلاقات الاقتصادية ولا مانعَ؛ فقد حدث تعارف في أثناء صلح الحديبية،

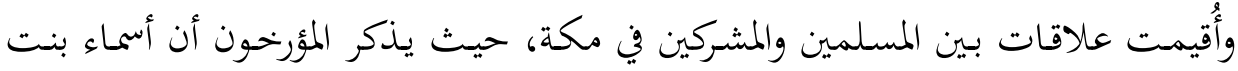

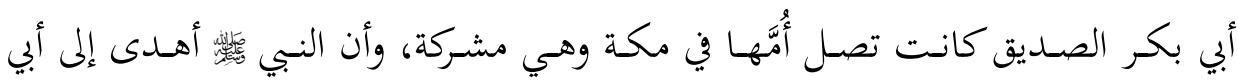

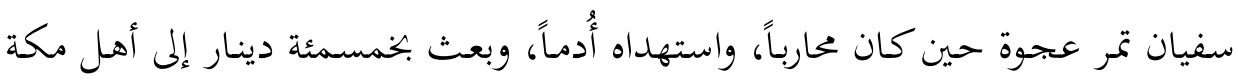
حين قحطوا، لتُوزَّع بين فقرائهم ومساكنهم.

فالإسـام ديـن رحمـة، ونظـام عـامي واقعي، يكتضـن السمُثل والآداب والقيم العليـا؛

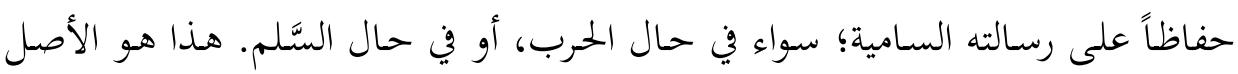

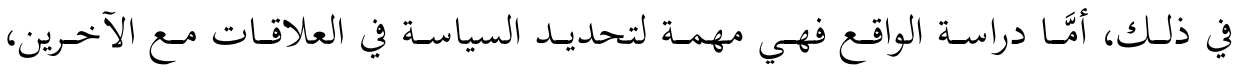

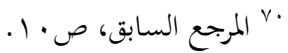

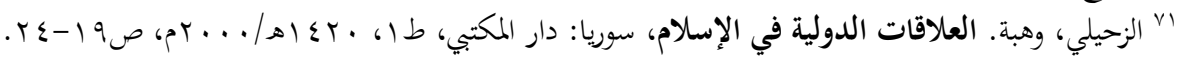




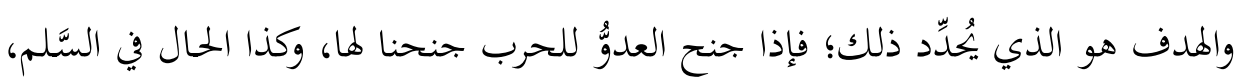

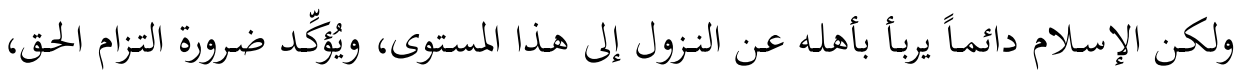

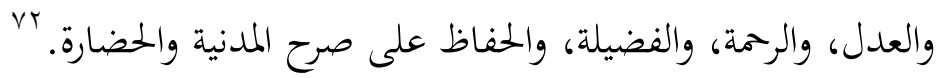

وتتمثَّل علاقة مقصد التعارف بهذا القانون في أنه إنساني في المقام الأول، وقد أطلق

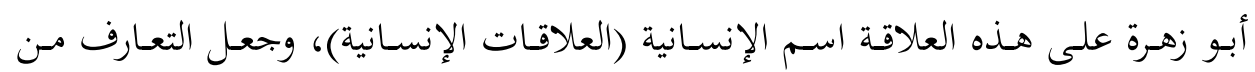

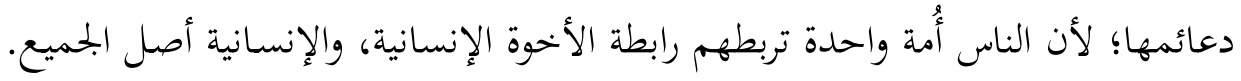

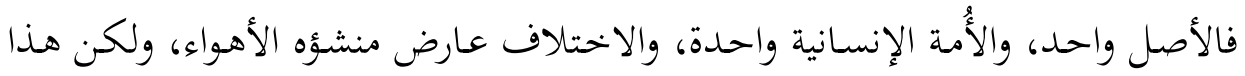

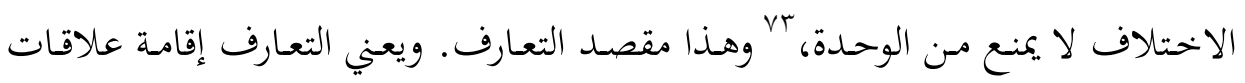

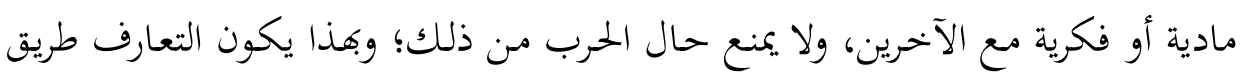

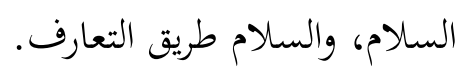

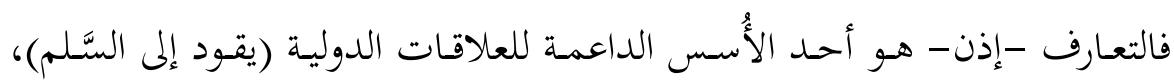

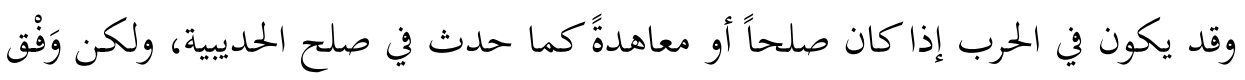

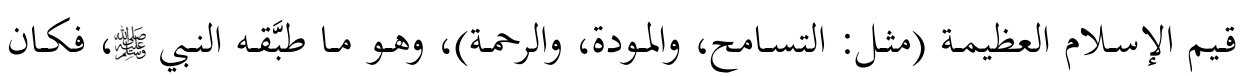
أعظم فتح في الإسلام.

واليوم نحن نعيش في عهد الأمم المتحدة، وبحلس الأمن، وعصبة الأمم التي تأسَّست

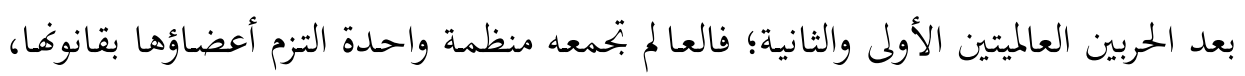

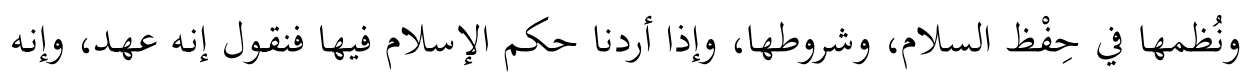

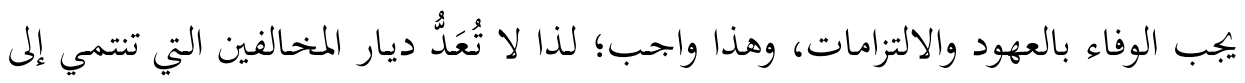

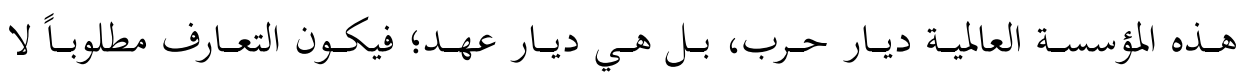

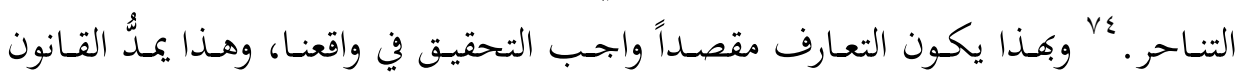

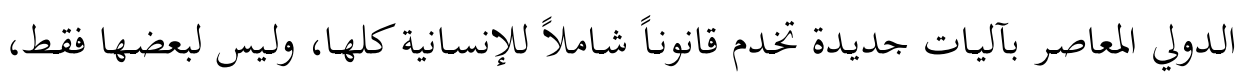

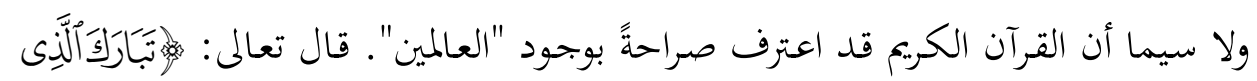

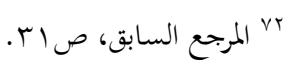

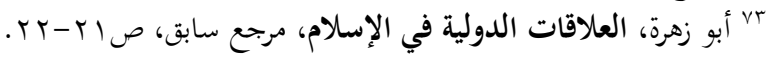

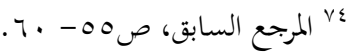




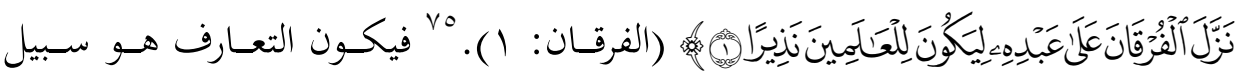

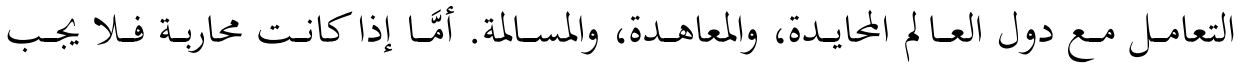

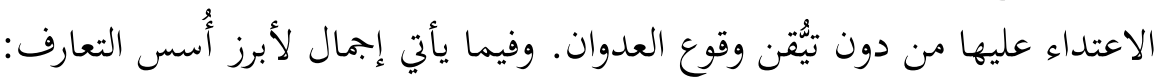

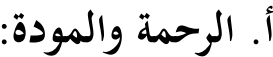

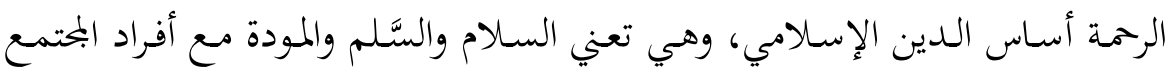

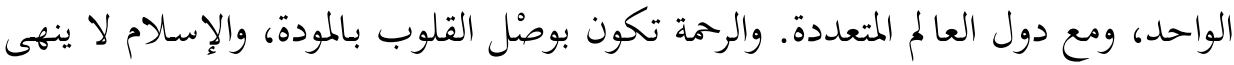

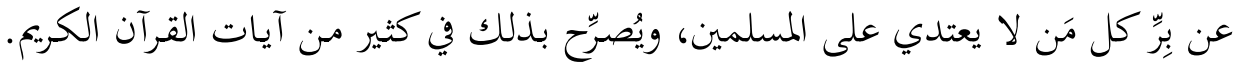

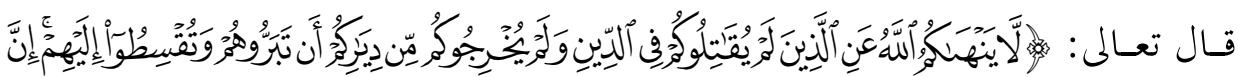

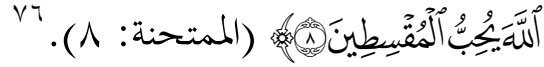

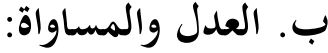

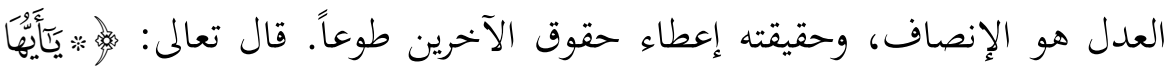

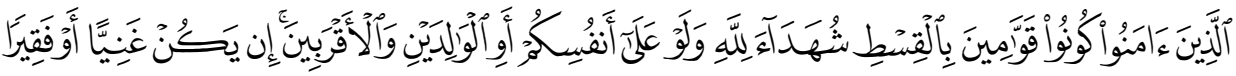

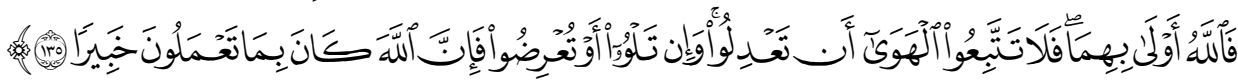

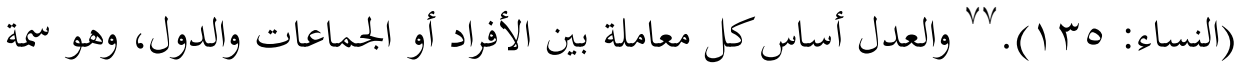

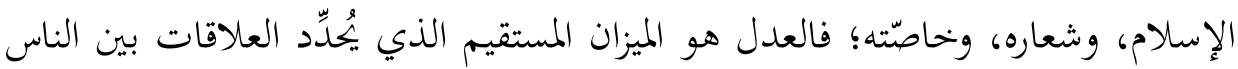

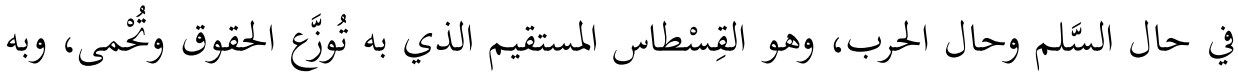

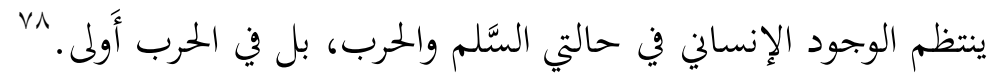

ومن العدل المساواة بين الناس، وهو وجهه من إقامة العدل؛ أي الاعتراف بالآخر،

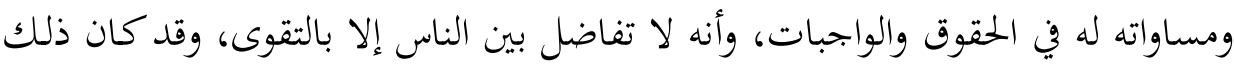

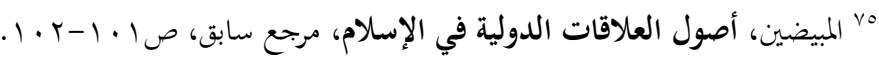

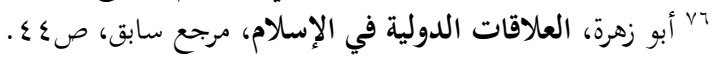

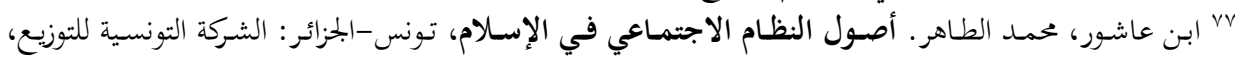

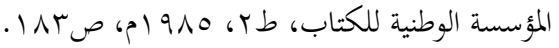

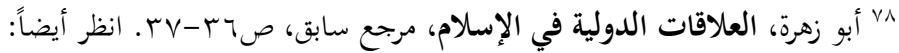

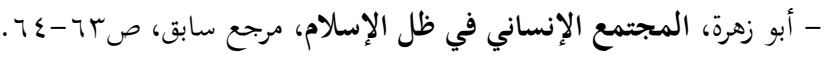




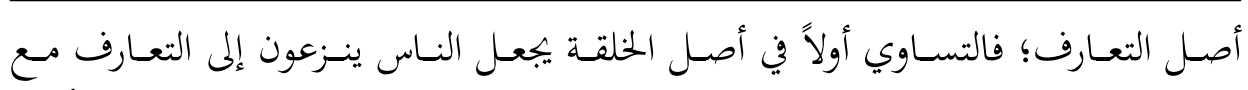

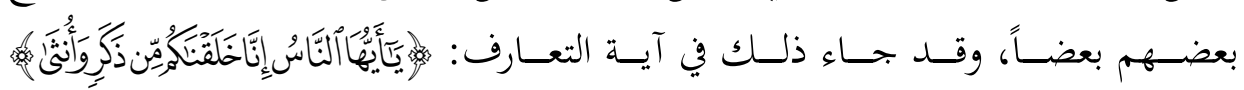

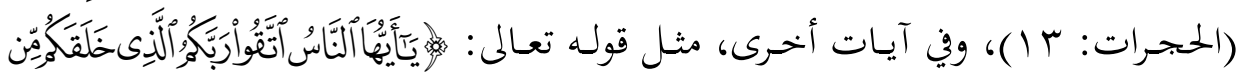

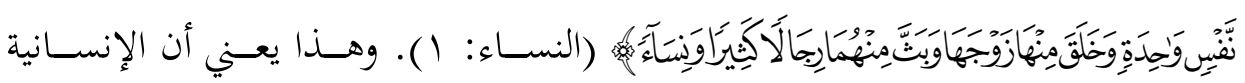

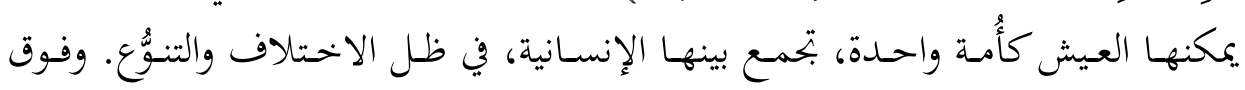
الإنسانية تبقى رابطة التقوى أرقى رابطة، وأكثر قوة للالتحام بين بني البشر. أمَّا التعامل

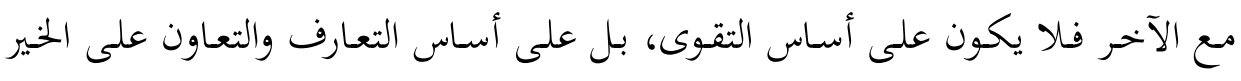
والمصلحة للجميع.

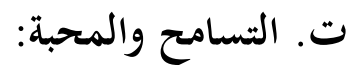

يُؤُثِّ التسامح -بوصفه مقصداً قيمياً- في الفقه الحضاري عامةً، والعلاقات الدولية بوجه خـاص، وهـو نفسُه مـا يقوم عليه قانون التعارف؛ إذ لا تعـارف مـ دون تسـامح ومحبة في إطار المشروع والمسموح، وهو -في حقيقته- يعني الرفق بالآخر والتجاوز عنه، والصَّفح غير الذليل مـن دون استسلام للشر أو تمكين له، كما قال أبو زهـرة. ‘وأثر

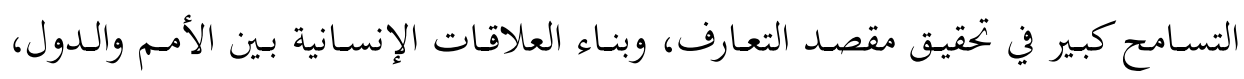

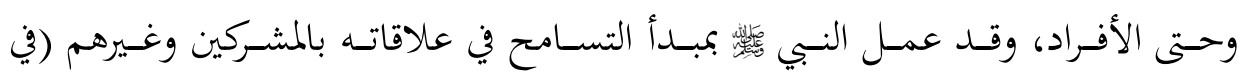
المعاهدات والحروب)، وبرز ذلك جلياً في صلح الحديبية حين قبل شرط أهل مكة بالرغم

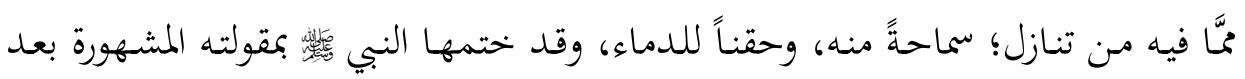

$$
\begin{aligned}
& \text { تيقُق النصر: "اذهبوا فأنتم الطلقاء". } \\
& \text { : انظر }
\end{aligned}
$$

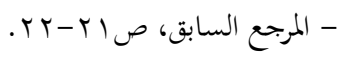

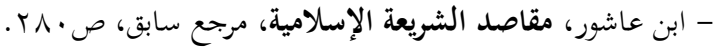

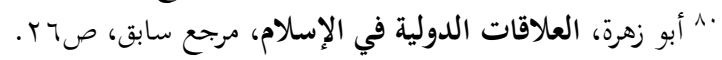




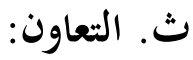

التعاون هو قيمة وأساس يقوم عليه مقصد التعارف الصحيح، بحيث تكتمل مصالح

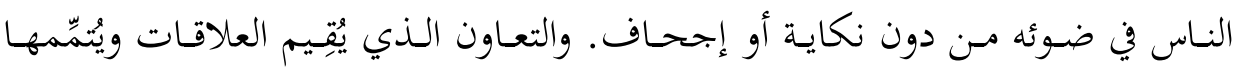

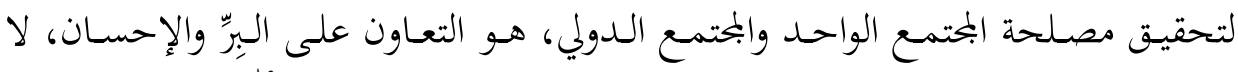

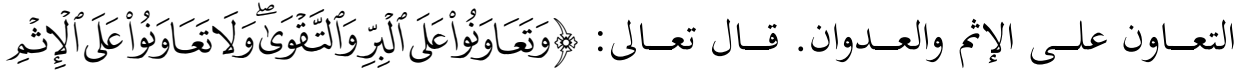

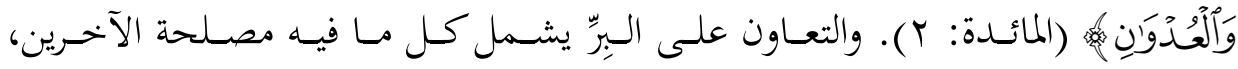

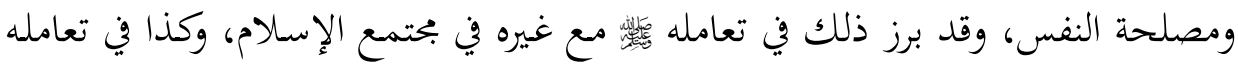

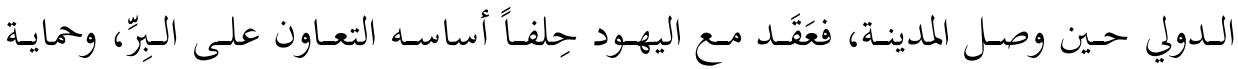

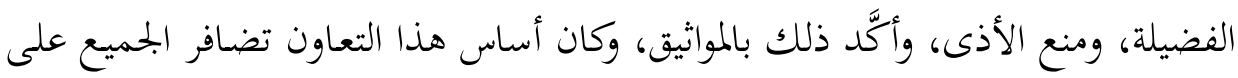

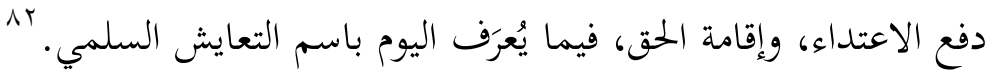

\section{ج. الأخوة الإنسانية والإيمانية:}

جاء الإسلام مُؤكّداً أخوة الناس كافة في الإنسانية، وأن البشر جميعاً من أصل واحد،

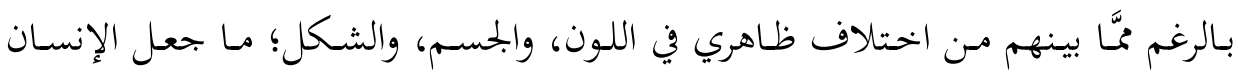

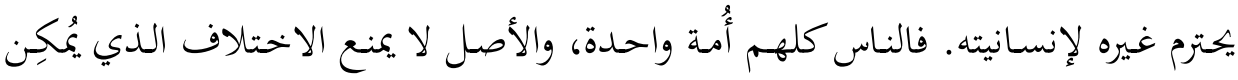

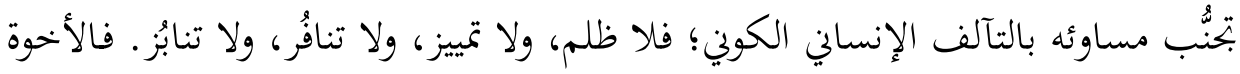

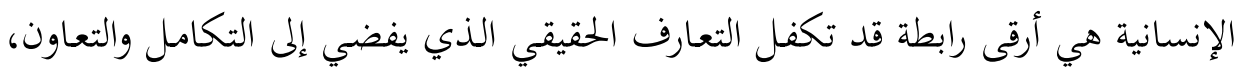

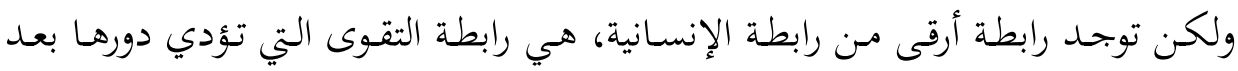
تعارف الناس بحكم الإنسانية.

فالإيمان علاقة عقدية تربط بين أتباع العقيدة الواحدة ليكونوا أكثر التحاماً وتماسكاً

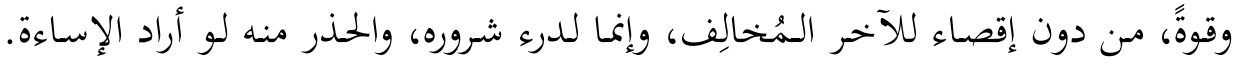

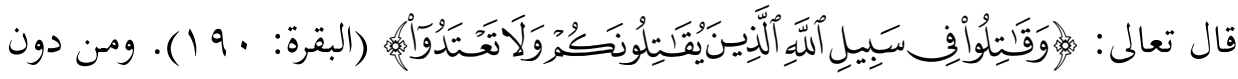

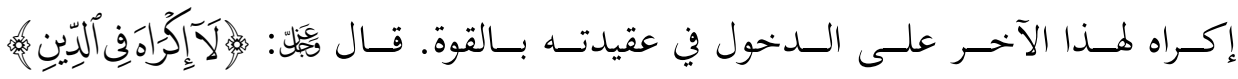




\section{ح. الحرية المكفولة للجميع:}

لا يمكن للإنسان أنْ ينال حقوقه بمنأى عن الحرية؛ فلا بُدَّ أنْ يكون حرَّاً في فكره،

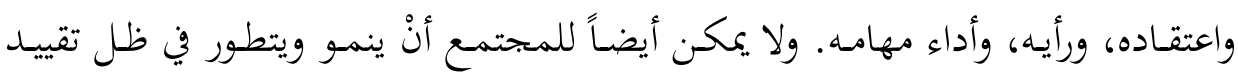

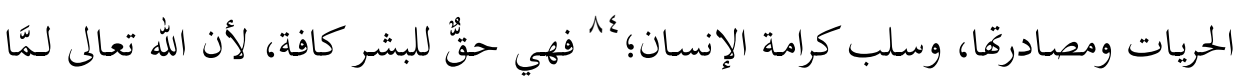

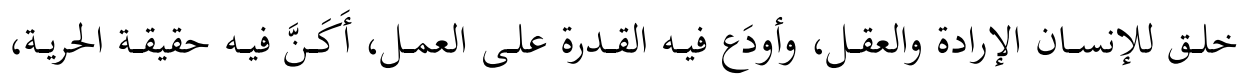

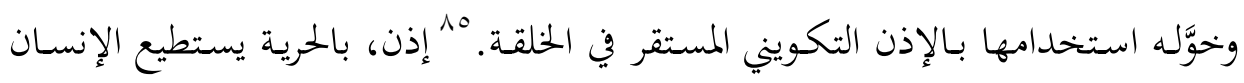

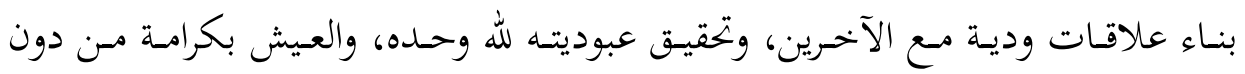
استعباد من أحد.

\section{خ. الفضيلة:}

يُوَِّّد الإسلام أن التمسك بالفضيلة هو أساس مهم في العلاقات الإنسانية؛ سواء

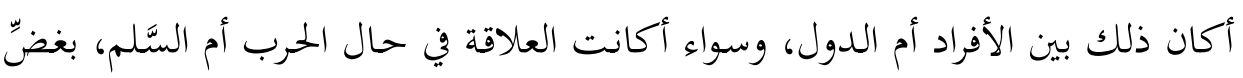

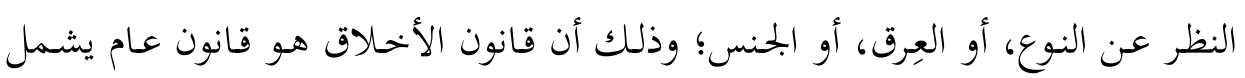

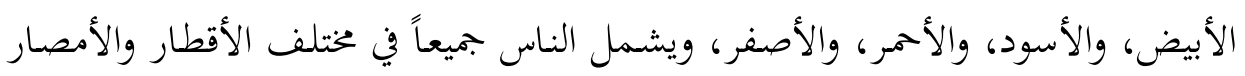

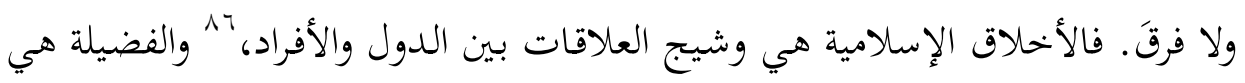

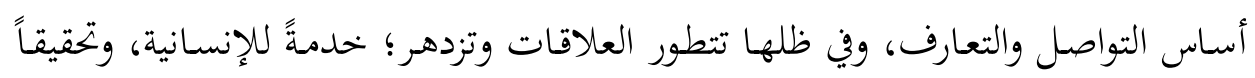

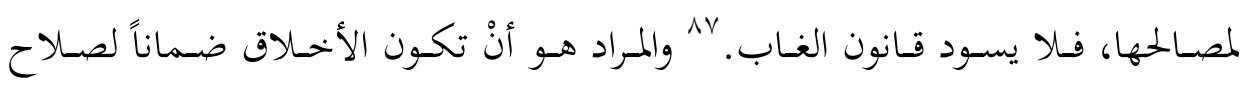

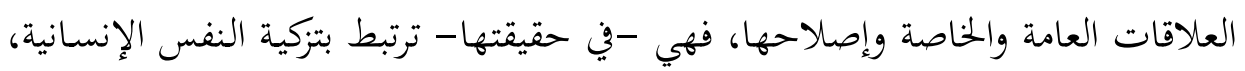

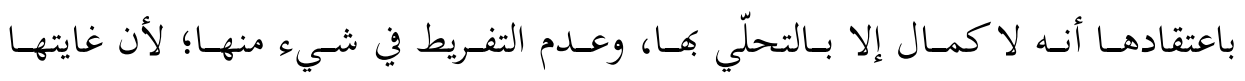

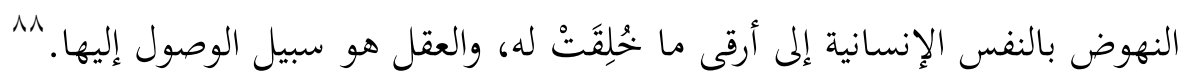

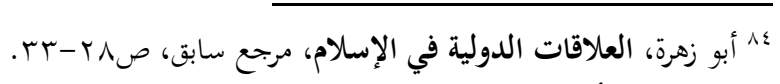

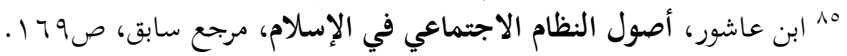

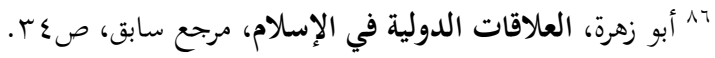

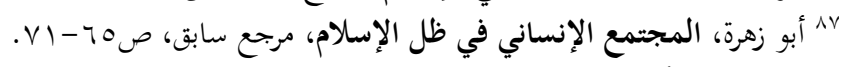

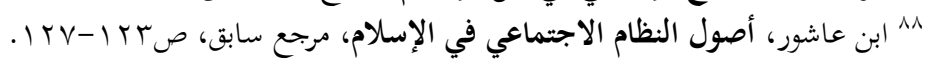


خاتمة:

يوصف الإسلام بأنه دين العالمية، وهو ما جعل تواصله مع الأفراد والجماعات يقوم على أُسس التعارف والتعاون والرقي؛ لبناء الأخوة الإنسانية، والوحدة العالمية التي محورها

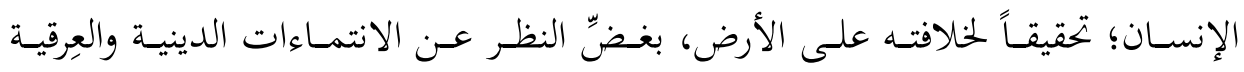

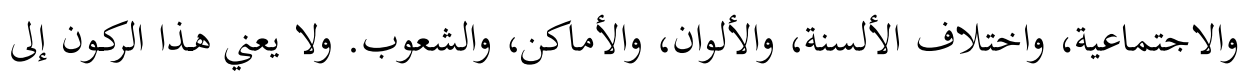

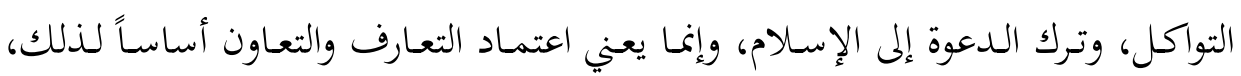

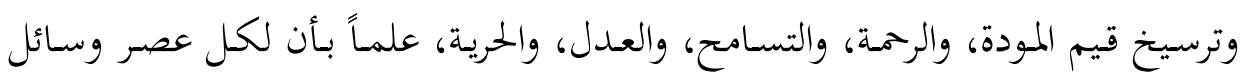

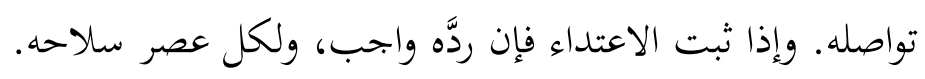
وقد انتهى البحث إلى بحموعة من النتائج بُجمِلها فيما يأني:

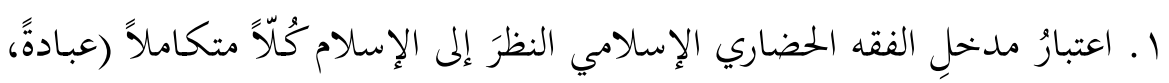

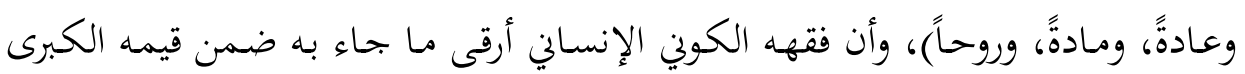
القطعية.

ץ. أهـم أسـس الإسـلام هي قيمـه الحضـارية العالميـة، التي تُعنى بـالفرد مثلمـا تُعنى

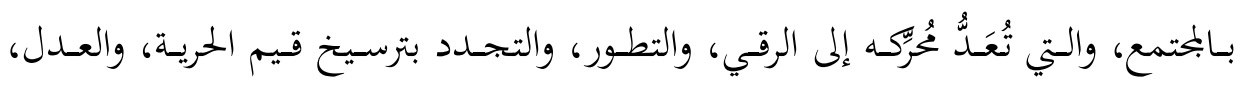

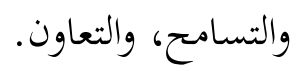

ب. فقه العلاقات الدولية وأُسسها جزء من الفقه الإسلامي، وهو أوسع أبوابه، لكن الكتابة فيه تحتاج إلى بحديد.

ع. أسـاس التعامل مع الآخر في ظل الاختلاف هـ التعارف، لا التناحر والتعـالي

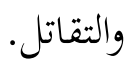

ه. التعارف في ظل التنوُّع والاختلاف هو التكامل والتعاون على تحقيق خلافة الله على الأرض، حتى يسود السالام والوئام. 
ج ـ منطق القوة في الإسلام له آلياته وأسبابه، التي تختلف باختلاف العصر والزمان. والتطور التكنولوجي السلمي في عصرنا هو أفضل طريقة لعرض تعاليم الإسلام ورسالته السمحة.

V. قـوة الإسـالام المعاصـرة تكـون بإثبـات قدرتـه على العـيش في ظل التطور التقـي والمادي، ولا سيما أنه يرقى عليه بقوته الروحية. فالصراع الحضاري يُشتِم علينا عرض آيات

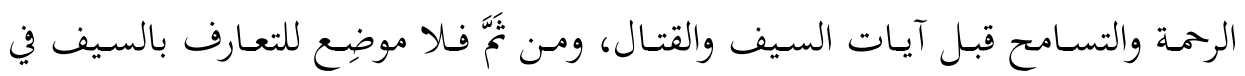
عصرنا، وإنما السـيف هـو العلم والقـوة العلميـة التكنولوجيـة، التي هـي سـبيل نشـر القـوة الروحيـة؛ لأن الإسـلام مـا جـاء إلا لإصـلاح ح أوضـاع البحتمع، لا للخضوع لها. وإذا ثبـت الاعتداء فالدفاع مطلوب لا محالة. أمَّا أهم التوصيات التي خرج بها البحث فهي: ا ـ وجوب تطوير معنى الفقه الإسلامي، وإعـادة النظر في هذا المعنى بحيـث يشمل التنظير للقضـايا الكـبىى بمـوازاة القضـايا الصغرى، والكتابـة في فقـه الجماعـة كمـا في فقـه الفرد.

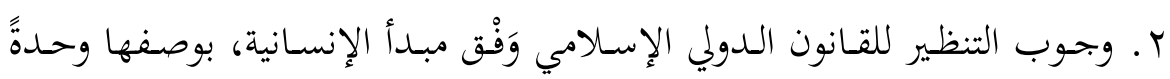

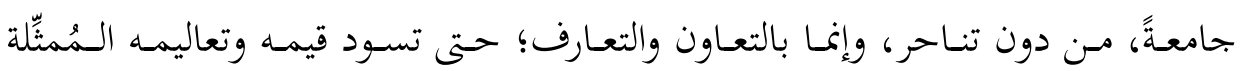
للدين الذي اختاره الله تعالى للعالمين. وجوب الكتابة في فقه التعارف وأُسسه، وتنزيلها على أرض الواقع، والخروج بقواعد تَهفل بالإنسانية كلها، وتطمح إلى سَنِّ قوانين عالمية عادلة. 